\title{
Reappraisal of the 'early proterozoic gabbro-anorthosite suite' rocks from the eastern Singhbhum craton, India: Insights from field features, petrography-mineralogy and geochemistry
}

\author{
Tushar Mouli Chakraborti, Arijit Ray* and Gautam Kumar Deb \\ Department of Geology, Presidency University, 86/1 College Street, Kolkata 700 073, India. \\ *Corresponding author.e-mail: rayarijit22@gmail.com
}

MS received 21 October 2018; revised 22 May 2019; accepted 4 June 2019

The present study focuses on six mafic-ultramafic units from eastern Indian Singhbhum craton: (i) gabbroic rocks of Galudih, (ii) dolerite from North of Bisoi, (iii) Bangriposi wehrlite (BW), (iv) dolerite from North of Kuliana, (v) Kuliana-layered gabbro (KLG) and (vi) dolerite of Jashipur. These rocks had been grouped earlier as a co-genetic unit titled 'early proterozoic gabbro-anorthosite suite'. Dolerites of Jashipur, North of Bisoi and North of Kuliana are found as undeformed intrusives into the Mesoarchaean Mayurbhanj granite (MBG) unit and show hydrothermal alteration features and variable LREE enrichment. Multiply-deformed gabbroic rocks of Galudih also intrude the MBGs with similar hydrothermal alteration features and comparatively lower REE abundances. KLG and BW are found as dismembered rocks, emplaced within a multiply-deformed metasedimentary assemblage of Mid-Proterozoic North Singhbhum mobile belt. Through a critical assessment of their field features, petrography, mineralogy and geochemistry, the earlier grouping was found to be invalid. Instead, these rock units should be categorised into three groups: Group I (Galudih), Group II (Jashipur, North of Bisoi, North of Kuliana) and Group III (KLG and BW). Group I rocks are the oldest among them, but their stratigraphic affinity remains unclear. Group II mafic rocks possibly belong to the Proterozoic newer dolerite dykes, whereas Group III represents fragments of oceanic crust and mantle.

Keywords. Mafic-ultramafic rocks; Singhbhum Craton; petrography; geochemistry; field features.

\section{Introduction}

The Palaeoarchean Singhbhum Craton (SC) of east India hosts a plethora of mafic-ultramafic rocks of different ages and types (Bose 2009). The oldest mafic rocks reported from this terrain are the metavolcanic rocks from the Palaeo-Mesoarchaean Older Metamorphic group (OMG; Manikyamba et al. 2015; table 1). Subsequent records of mafic volcanism and plutonism span for almost 2 billion years, up to Neoproterozoic represented by mafic Published online: 08 August 2019 dykes belonging to the Newer Dolerite Dyke (NDD) swarm (Misra 2006; table 1). These groups of mafic-ultramafic rocks differ significantly in terms of mineralogical and geochemical characteristics and numerous debates exist regarding their petrogenesis. The present study focuses on one such group of mafic-ultramafic rocks from the eastern part of SC, dubbed as the 'early proterozoic gabbro-anorthosite suite' by Saha (1994; figure 1). The presence of these rocks was recognised in the first half of the 20th century, but they have not 
Table 1. Stratigraphic succession of the SC, east India.

\begin{tabular}{|c|c|c|}
\hline Unit & Age $(\mathrm{Ga})$ & Reference \\
\hline NDDs & $2.8-1.0$ & $\begin{array}{l}\text { Misra (2006), Shankar et al. (2014), } \\
\text { Kumar et al. (2017) }\end{array}$ \\
\hline NSMB metasedimentary rocks & $1.6-1.5$ & Pandey et al. (1986) \\
\hline Kolhan group & $<2.25$ & Misra and Johnson (2005) \\
\hline Jagannathpur and Malangtoli lavas & 2.25 & Misra and Johnson (2005) \\
\hline Dhanjori and Dalma volcanic & $<2.8$ & Singh et al. (2016) \\
\hline Tamperkola granite & 2.8 & Bandyopadhyay et al. (2001) \\
\hline MBG & 3.09 & Misra et al. (1999) \\
\hline Sukinda-Nuasahi complex & 3.1 & Auge et al. (2003) \\
\hline BGG & $3.12-3.08$ & Chakraborti et al. (2019) \\
\hline Simlipal lavas and metasediments & $>3.09$ & Misra (2006) \\
\hline Singhbhum granite-III (SBG-III) & $3.12-3.05$ & $\begin{array}{l}\text { Chakraborty and Majumder (1986), } \\
\text { Ghosh et al. (1996) }\end{array}$ \\
\hline Bonai granite (BNG) & 3.16 & Sengupta et al. (1991) \\
\hline Nilgiri granite (NG) & 3.29 & Vohra et al. (1991) \\
\hline Singhbhum granite-II (SBG-II) & $3.33-3.30$ & Ghosh et al. (1996), Misra et al. (1999) \\
\hline Singhbhum granite-I (SBG-I) & 3.44 & Ghosh et al. (1996) \\
\hline $\begin{array}{l}\text { Older metamorphic tonalitic gneiss } \\
\text { (OMTG) }\end{array}$ & $\begin{array}{l}3.45-3.44 \& \\
3.35-3.32\end{array}$ & Upadhyay et al. (2014) \\
\hline Iron ore group (IOG) & $3.5-3.12$ & $\begin{array}{l}\text { Ghosh et al. (1996), } \\
\text { Mukhopadhyay et al. (2008) }\end{array}$ \\
\hline OMG & $3.55-3.44$ & Misra (2006) \\
\hline Unstable sialic crust & $>3.6$ & Goswami et al. (1995) \\
\hline
\end{tabular}

been studied in detail. As a result, many conflicting views exist on the temporal and stratigraphic status of these rocks. Although no census has yet been reached on the tectonic characterisation of these rocks, the grouping of Saha (1994) has never been critically examined and has been carried forward by more recent studies (Auge et al. 2003; Misra 2006).

Seven individual units of mafic-ultramafic rocks belonging to this group have been identified in the present study. From the north to the south, they are: (i) gabbroic rocks of Galudih, (ii) dolerite from North of Bisoi, (iii) wehrlite of Bangriposi (Bangriposi wehrlite 'BW'), (iv) dolerite from North of Kuliana, (v) layered gabbro of Kuliana (Kulianalayered gabbro 'KLG'), (vi) dolerite of Jashipur and (vii) mafic-ultramafic rocks of Sukinda-Nuasahi. Among these units, the ultramafic rocks of Sukinda-Nuasahi have been extensively studied, partly due to their ore-bearing nature (Page et al. 1985; Banerjee 1997; Mondal et al. 2006, 2007). These rocks have yielded a Mesoarchaean age $(\sim 3.1 \mathrm{Ga}$; table 1$)$ and have been hypothesised to form in a supra-subduction zone setting (Mondal et al. 2006). Detailed studies have been performed by the current authors on mafic-ultramafic rocks of Bangriposi and Kuliana (Chakraborti et al. 2016, 2017, 2018), which revealed that the layered gabbro and wehrlite units are co-genetic, and represent fragments of oceanic crustal magma chambers and the underlying metasomatised mantle, respectively (Chakraborti 2018).

As of yet, the 3.1 Ga age of the Sukinda-Nuasahi complex (table 1) remains the only precise and direct estimate of age among all of these rock units. Also, comprehensive field and petrological studies have not been initiated on these rock units to understand and evaluate their stratigraphic position which has compounded the problem to a much greater degree. This study presents new data on the mafic rocks of Galudih, North of Bisoi, North of Kuliana and Jashipur, and provides a review on the work about the Gabbro-wehrlite suite of Bangriposi-Kuliana. The Sukinda-Nuasahi complex has an established age (Auge et al. 2003) and it was found through straightforward stratigraphic considerations that they represent a much older phase of mafic igneous activity than the rest of the undated units. Hence, they have been treated as a separate entity and have been left out in the present discussion. The principle objective of this work is to examine the present grouping of these mafic-ultramafic rocks of the SC, through detailed field features, mineralogy and geochemistry, and to get an idea about the petrogenetic histories of these rocks. 


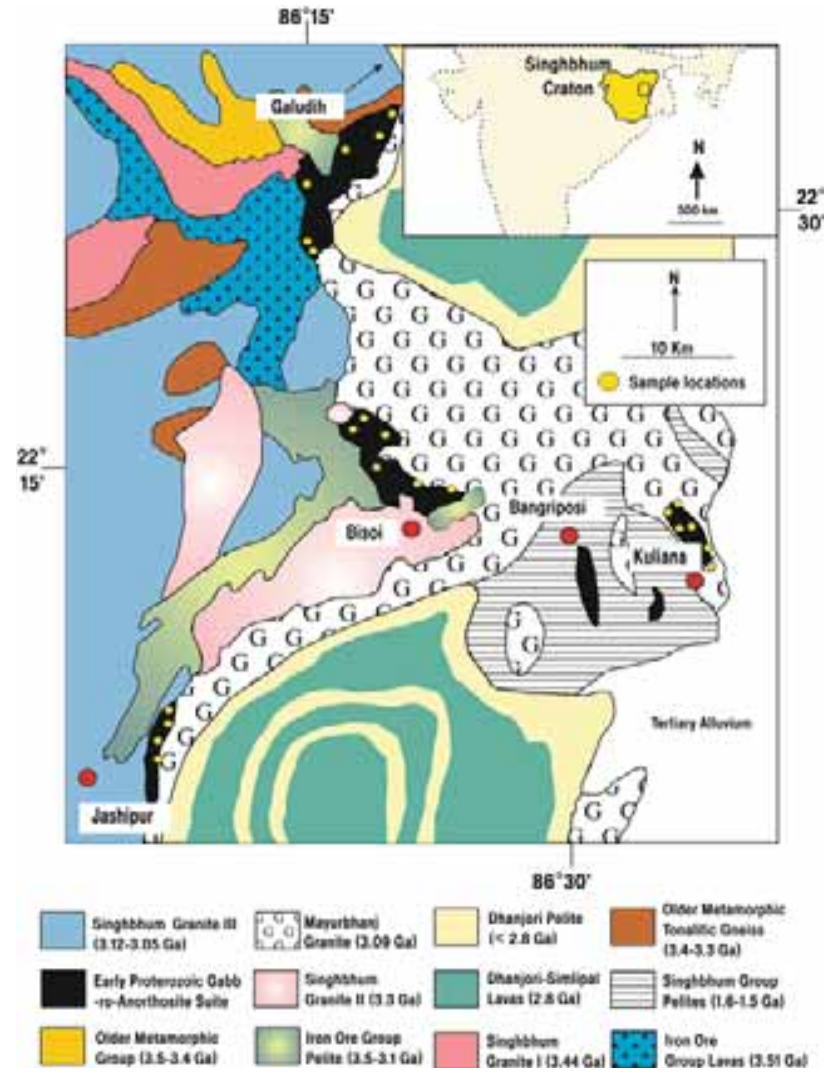

Figure 1. Lithological map of the study area with the 'early proterozoic gabbro-anorthosite suite' rock units marked with black. Inset: Map of India showing the position of the SC. The area of study has been marked with a black rectangle. The published ages of the lithounits depicted in the map have been given (references same as table 1).

\section{Regional geology}

The mafic-ultramafic rocks of the 'early proterozoic gabbro-anorthosite suite' are found in the eastern part of the SC. The northern section of this region is dominated by the $3.09 \mathrm{Ga}$ Mayurbhanj granite (MBG; table 1; Misra et al. 2002). Proterozoic supracrustals such as the North Singhbhum mobile belt (NSMB) assemblage and the Simlipal complex dominate the middle and the lowest sections of this region (figure 1). NSMB rocks are mainly represented by alternating quartzite and phyllite bands with conglomerates and minor metamorphosed mafic rocks. Recent workers have considered the NSMB metapelites as Mesoarchaean (Misra 2006) and associated their deposition and deformation with the intrusion of MBG. However, the reigning popular view is still the older assertion that the NSMB represents a MidProterozoic orogenic belt assemblage (table 1; Pandey et al. 1986; Saha 1994; Chatterjee et al. 2013; Mazumder et al. 2015). The Simlipal complex is a volcano-sedimentary unit, dominated by spilitic lavas and tuffs, alternating with quartzite bands. Studies on these rocks are sparse, and recent workers have assumed a Mesoarchaean age (Misra 2006) and a plume-related origin (Banerjee and Ghosh 1994). The mafic rocks of the Galudih mark the northernmost extent of this region and are in close association with the MBG rocks as well. The MBG separates the mafic rocks of Galudih from the Neoarchean Dhanjori rocks (1 Ga; table 1). Isolated bodies of alkali feldspar granite-gneiss outcrop near the NSMB metapelite-dominated Bangriposi sector. This granite body, dubbed as the 'Bangriposi Granite-Gneiss (BGG)', has been studied in detail by the present authors (Chakraborti et al. 2019). This Mesoarchaean ( 3.08$3.12 \mathrm{Ga}$; table 1) high-K granitic unit represents a widespread crustal reworking activity in the SC. MBG rocks range from ferrohastingsite-biotite granite to granophyric microgranite and aplogranite. They are mostly undeformed, except for local N-S trending shearing near its eastern margin (Misra et al. 2002), which has been attributed to be the effects of the southern extension of the Singhbhum shear zone (SSZ) (Naha 1965). This extension of SSZ, now categorised as the Bangriposi shear zone (BSZ) (Prabhakar et al. 2014) is present close to the gabbro-wehrlite rocks of the Bangriposi-Kuliana sector.

Earliest workers categorised these mafic-ultramafic rocks as coeval with the rocks of the basic volcanics dominated iron ore group, and thus older than the Singhbhum granite (table 1; Dunn and Dey, 1942). Based on field relations from some other locations in the eastern Indian shield, Sarkar and Saha $(1962,1963)$ interpreted a younger age of the mafic-ultramafic rocks relative to the Singhbhum granite. Furthermore, in contrast to the view of the co-magmatic evolution of these rocks and the MBG, as inferred by Iyengar and Alwar (1965), a relatively older age of the former has been suggested (Saha et al. 1977). Saha (1994) subsequently compiled the information together and classified these mafic-ultramafic rocks as 'early proterozoic gabbro-anorthosite suite', and associated them with Ti-V bearing ore bodies. Auge et al. (2003) proposed a $3.1 \mathrm{Ga}$ age of these rocks based on $\mathrm{U}-\mathrm{Pb}$ zircon analysis from the Bangur gabbro unit, within the Sukinda-Nuasahi mafic-ultramafic complex. Misra (2006) considered these mafic-ultramafic rocks as coeval with the MBG and also proposed a Mesoarchaean relative age $(\sim 3.09 \mathrm{Ga}$; table 1). More recently, Prabhakar et al. (2014) 

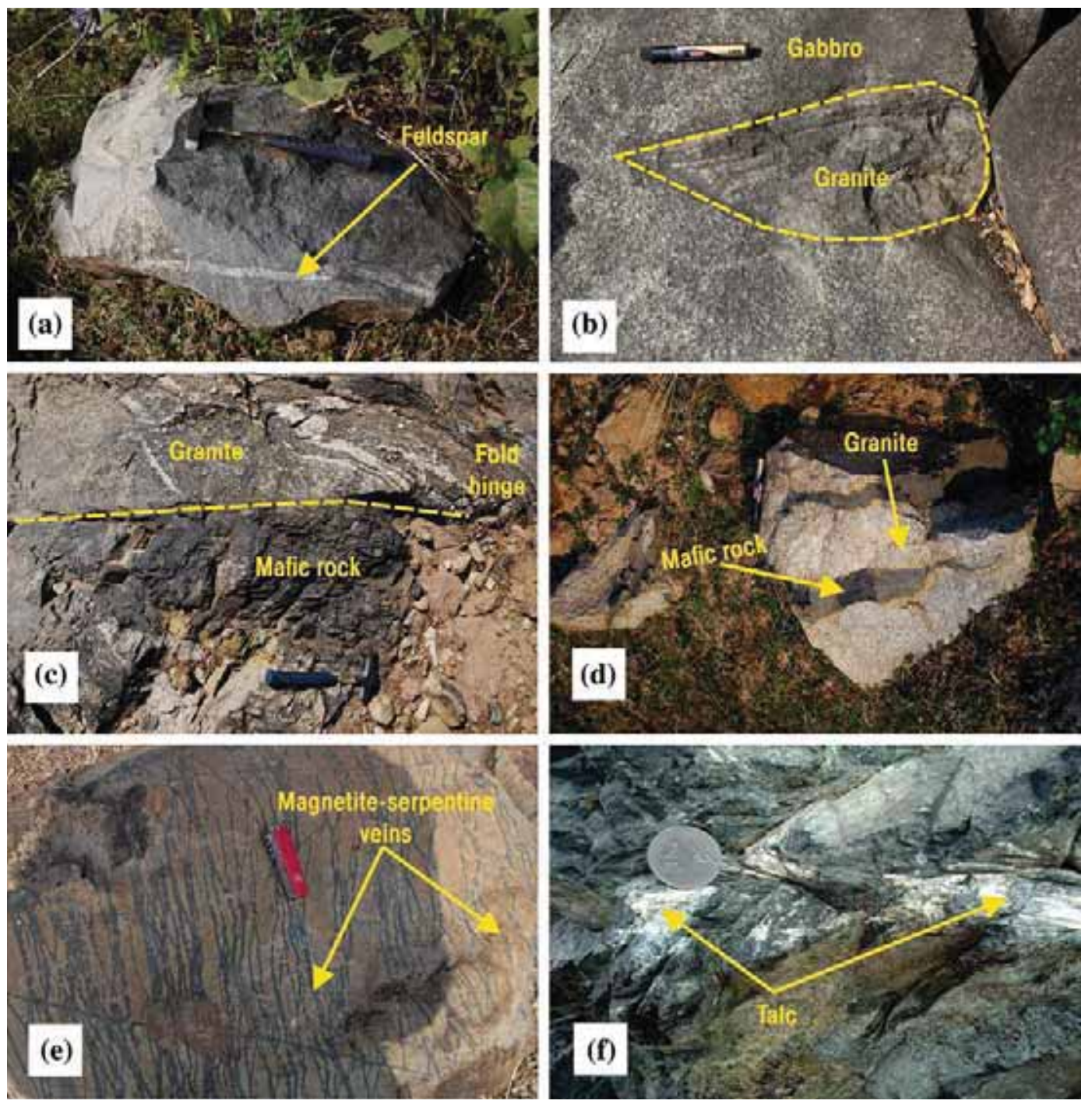

Figure 2. (a) Gabbroic rocks of Galudih with a feldspar layer. (b) A xenolith of MBG within the gabbroic rocks of Galudih. (c) A fold hinge of the MBG being cut by a fine-grained dolerite dyke from the North of Bisoi. (d) An apophytic tongue of dolerite from the North of Bisoi within the granitic country rocks. (e) The relatively less serpentinised parts of BW showing a network of magnetite-serpentine veins. (f) Highly serpentinised parts of BW with prominent talc growth.

studied the gabbro and associated wehrlite rocks of Bangriposi, and suggested that the mafic-ultramafic rocks along with the metasediments of the region constitutes a $\sim 1.0 \mathrm{Ga}$ tectonic mélange, interleaved with the granitic crustal components. This range of conflicting assertions spanning almost $80 \mathrm{yr}$, basically stems from the lack of direct geochronological data of these rocks.

\section{Geology of the early proterozoic gabbro- anorthosite suite}

The gabbroic rocks of Galudih are located in the town of Kalikapur $\left(22^{\circ} 37^{\prime} \mathrm{N} ; 86^{\circ} 17^{\prime} \mathrm{E}\right)$, westsouthwest of Galudih, and are found within granitic rocks of the MBG suite. The small, rectangular mafic unit has a maximum lengthwise extension of $2 \mathrm{~km}(\mathrm{~N}-\mathrm{S})$ and is about 500 700 metres wide. The main rock type observed was coarse-grained gabbro, with the presence of finergrained parts observed near the contact with the granitic rocks. Felsic layers, mainly composed of quartzo-feldspathic minerals, have been seen in some parts of the body (figure $2 \mathrm{a}$ ). The layering is about $10-190^{\circ}$ at the southern end of the body and becomes parallel to foliation near its northern parts. Although not conspicuous throughout the whole body, some parts appear foliated in the field with the orientation of the foliation being $140-320^{\circ}$. The surrounding area primarily consists of greyish-coloured, foliated granites and 
xenoliths of these foliated granites have been found in the mafic body (figure 2b). This suggests that the gabbroic rocks of Galudih are younger than the surrounding MBG rocks (table 1).

Dolerite rocks from North of Bisoi $\left(22^{\circ} 9^{\prime} 30^{\prime \prime} \mathrm{N}\right.$; $\left.86^{\circ} 24^{\prime} 30^{\prime \prime} \mathrm{E}\right)$ are found within granitic rocks belonging to the MBG pluton (Misra 1999; Misra et al. 2002). These mafic rocks are medium- to finegrained and appear as isolated bodies with low elevations. These generally have lengths $<800 \mathrm{~m}$ and widths $<50$ to $60 \mathrm{~m}$. Finer grain size varieties are observed near the contact with the granites. In some cases, it was found that the mafic rocks cut across a fold hinge of the granitic rocks (figure 2c). Also, extremely fine-grained apophytic tongues are seen within the granitic rock (figure 2d). The development of a planar structure is not seen, and from the field observation, it can be stated that these mafic rocks are largely undeformed. Enclaves of the foliated MBG are sometimes found in the dyke rocks. Overall, numerous evidence of intrusive activity such as the cross-cutting relationship, apophytic tongues and the presence of enclaves help classify them as mafic dykes.

Wehrlite rocks of Bangriposi $\left(22^{\circ} 9^{\prime} \mathrm{N} ; 86^{\circ} 32^{\prime} \mathrm{E}\right)$ occur as an $\mathrm{N}-\mathrm{S}$ trending, elongated $\mathrm{Cr}$-spinel bearing serpentinised wehrlite unit. The rocks are situated close to the BSZ within NSMB metapelites, but do not exhibit any evidence of intrusive activity (chilled margins, apophytic tongues, feeder dykes, etc.). The relatively less serpentinised southern end of this unit is characterised by a network of magnetite-serpentine veins (figure 2e). The northern part has prominent talc growth (figure 2f) and has been completely transformed to talc-tremolite schists. These rocks have an N-S trending east dipping foliation. The gabbro unit is situated south-west of the wehrlite near Kuliana $\left(22^{\circ} 3^{\prime} \mathrm{N} ; 86^{\circ} 38^{\prime} \mathrm{E}\right)$. They occur within NSMB quartzites and grade from gabbro to anorthositic gabbro. As with the ultramafic rocks, these rocks also lack any evidence of intrusive nature. The rocks display excellent modal layering and mineral laminations, with textural and cryptic layering. The laminations of pyroxene (figure 3a) mark the gabbroic parts of the body, whereas plagioclase laminations (figure 3b) characterise the more felsic domains of this suite. The general trend of layering is NE-SW with a moderate $\left(\sim 60^{\circ}\right) \mathrm{SW}$ dip. Apart from this, there are no signs of deformation. For more details about the field features of these rocks, the reader is referred to Chakraborti et al. (2017). No direct geochronological data are available on these rocks and the absence of
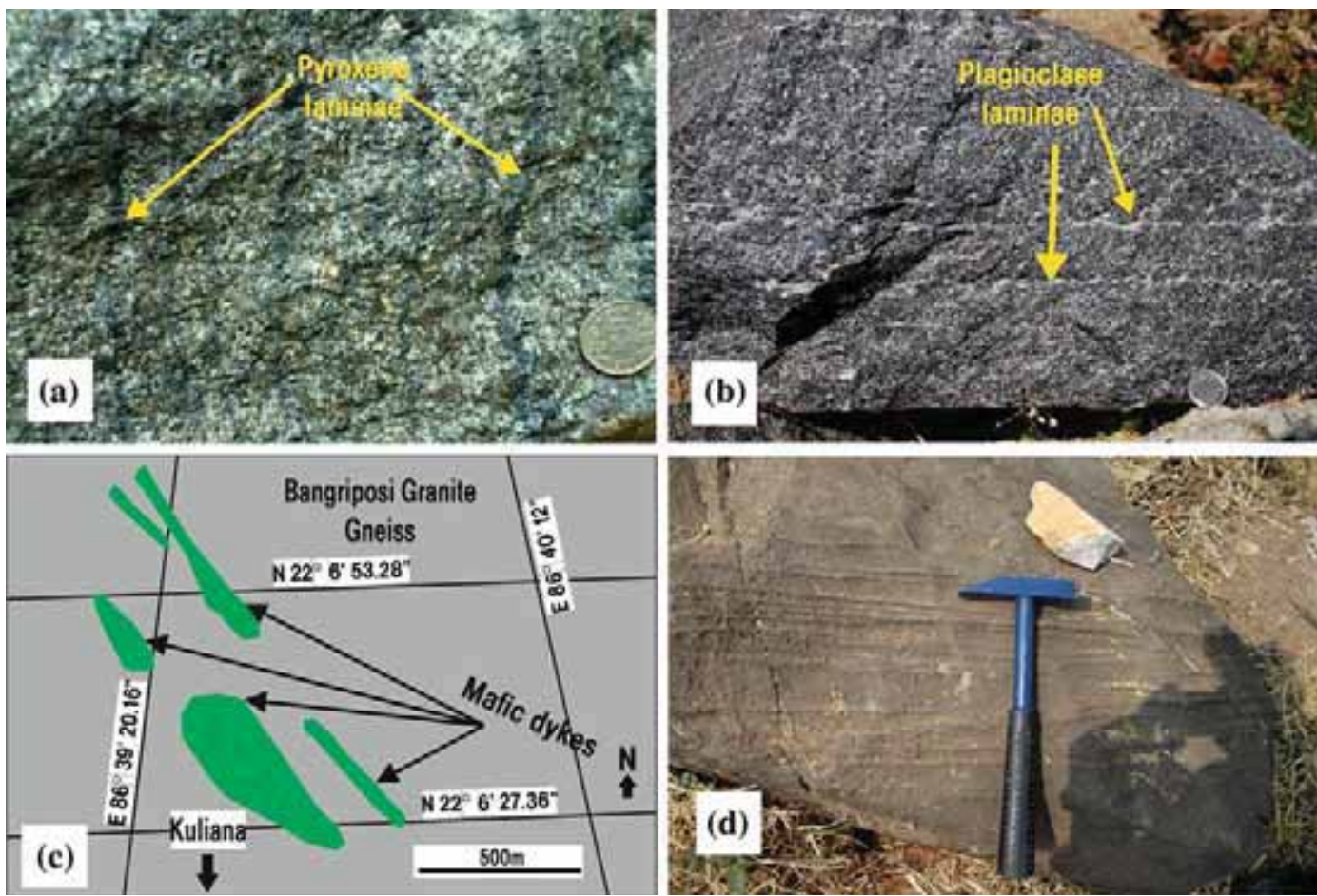

Figure 3. (a) Pyroxene laminae within gabbroic rocks from the KLG unit. (b) Feldspar laminae within leucogabbro units of KLG. (c) Lithological map showing the linear, dyke-like, NW-SE trending appearance of the doleritic rocks from North of Kuliana, within granitic rocks of the BGG suite. (d) Ridge-like vein network on the outcrop surface of dolerite from North of Kuliana. 
evidence of any intrusive activity in the field also hinders placing age constraints on them based on local stratigraphy. These rocks have been dubbed as the 'BW' and 'KLG' respectively, and will henceforth be referred to as such for the rest of this study.

Dolerite rocks from North of Kuliana occur within the BGG suite, and are medium to fine grained. They exhibit no evidence of deformation in the field. Although no direct contacts were observed in the field, their linear appearance (figure 3c) and restricted occurrence within deformed granitic terrain suggest that these rocks are mafic dykes. Also the marginal parts of these dykes exhibit predominance of relatively finer grain sizes. The general trend of these dykes is NW-SE (some rare E-W trending dykes are also observed), and in the field they appear as small, isolated hillocks, generally $<20$ to $25 \mathrm{~m}$ in height and $<700$ to $800 \mathrm{~m}$ in width. Some of the longer dykes (maximum length $\sim 2 \mathrm{~km}$ ) are found in the western part of the granitic body, and have relatively coarser grain sizes in their central part. Samples have a relatively melanocratic appearance in hand specimen, being primarily composed of feldspar and pyroxene. One interesting feature common throughout the entire suite is the presence of vein-like networks (figure 3d). These dark veins appear as ridges on the weathered outcrop surface and hence are composed of relatively resistant minerals. The network of veins shows no consistent orientation and sometimes becomes highly erratic in appearance, which suggests its secondary hydrothermal origin. Although no geochronological data of these rocks are available, their dyke-like appearance and undeformed nature suggest a probable younger age relative to the deformed-Mesoarchaean BGG suite (table 1).

The town of Jashipur is situated SSW of the Bangriposi-Kuliana region. One small, longitudinal mafic rock unit was located skirting the western margin of the Simlipal volcano-sedimentary complex (figure 1). These rocks are found as boulders and their freshly broken surfaces have a darkgreenish appearance, exhibiting coarse to medium grain size. Although this mafic body could not be traced completely in the field due to accessibility problems, it was evident from fieldwork that this unit has larger dimensions (length $>5 \mathrm{~km}$ ) than what was originally shown in the map of Saha (1994).

\section{Petrography}

Gabbroic rocks of Galudih have medium to coarse grain size with an inequigranular texture. Subophitic and intergranular textures are also observed. The primary constituent minerals are plagioclase and clinopyroxene, and both have euhedral to subhedral grain shapes. Two-main petrographic features of these rocks are: (i) the presence of two generations of deformation as depicted by the folding of the foliation (figure 4a) and (ii) ubiquitous evidence of low-temperature hydrothermal alteration. The foliation of these rocks is defined by amphibole and biotites. The crenulations are not evident throughout the thin sections, but an overall foliated character of the rocks can be easily discernible. The most conspicuous effects of hydrothermal alteration are sericitisation of plagioclase grains, clouding of plagioclase caused by the crystallisation of opaque phases (figure 4b), and uralitisation of clinopyroxene grains defined by the transformation to fibrous amphiboles (tremolite, actinolite etc.) along the grain margins (figure 4b). A type of quartz-alkali feldspar intergrowth, termed as the micropegmatite intergrowth, is also often seen in the grain interstices (figure $4 \mathrm{~b}$ ). Ilmenite is the only iron oxide phase observed within these rocks. Orthopyroxene is rarely observed and also exhibits effects of hydrothermal alteration in the form of bastitisation.

The majority of the dolerite dykes from North of Bisoi have medium to fine grain size exhibiting inequigranular, sub-ophitic and intergranular textures (figure 4c). These rocks are primarily made up of plagioclase and clinopyroxene, with accessory iron oxides and can be classified as dolerites. Orthopyroxene is found only in rare instances and is restricted to dykes with a coarse grain size. Plagioclase occurs in a bi-modal size distribution, with lath-shaped, euhedral grains and subhedral to anhedral larger grains. Clinopyroxene has a relatively smaller grain size and in some instances the grains show twinning. In one $\mathrm{N}-\mathrm{S}$ trending dyke about $200 \mathrm{~m}$ long, the grain size is the coarsest with a significant amount of orthopyroxene. All mineral phases are euhedral to subhedral and display textural features akin to cumulus texture. Plagioclase also occurs in two modes, but the interesting feature of this dyke is that extremely large plagioclase grains appear to enclose almost all other grains within them (figure 4d). All other grains, even smaller plagioclase grains are observed 

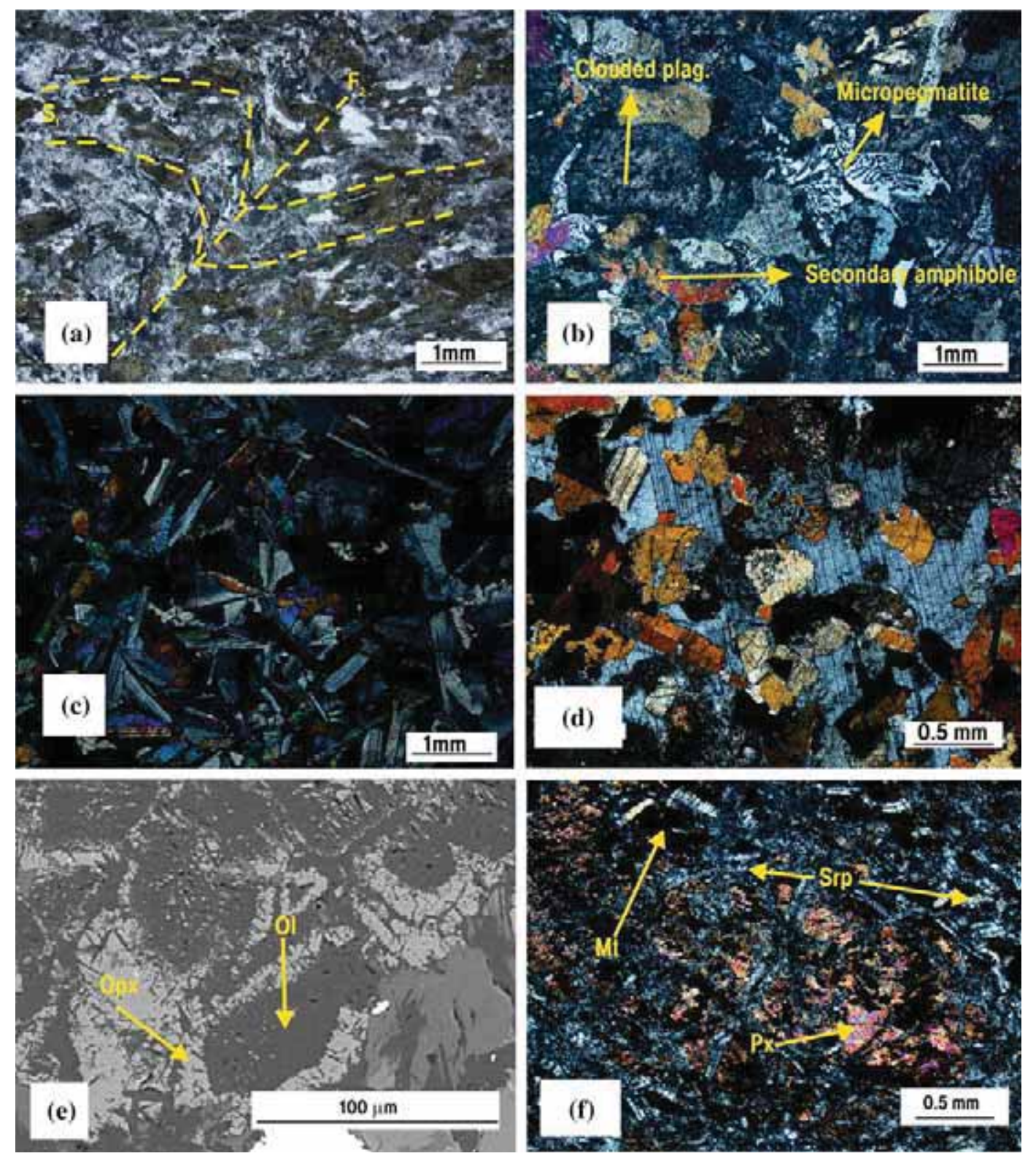

Figure 4. (a) Photomicrograph under plane-polars showing folded foliation defined by hornblende grains, from the gabbroic rocks of Galudih. (b) Photomicrograph under cross-polars showing hydrothermal alteration features from the gabbroic rocks of Galudih. (c) Photomicrograph under cross-polars showing the typical doleritic texture defined by plagioclase laths and pyroxene, from mafic rocks of North of Bisoi. (d) Photomicrograph under cross-polars from a coarse-grained dolerite dyke from North of Bisoi, showing large plagioclase grains with inclusions of subhedral pyroxene. (e) Back-scattered electron image showing secondary orthopyroxene rims around serpentinised olivine grains from the BW rocks. (f) Photomicrograph under cross-polars showing the typical mesh-texture defined by serpentine and magnetite with altered pyroxene from BW (Ol: olivine, Px: pyroxene, Mt: magnetite, Srp: serpentine).

as inclusions within the large-plagioclase grains. A probable explanation could be that the residual liquid became plagioclase-rich and formed under relatively slow cooling conditions. Evidence of hydrothermal alterations is minimal, and only some clinopyroxene shows alteration to fibrous amphiboles along grain margins or fractures. Spinels are sometimes seen as inclusions within pyroxene grains. Apart from silicate phases, both magnetite and ilmenite are observed as iron oxides, with minor sulphides (pyrite and chalcopyrite).

The BW unit shows evidence of pervasive serpentinisation being composed of serpentinised olivine pseudomorphs, clinopyroxene, Cr-spinel, magnetite, tremolite/actinolite, vermiculite, apatite and minor brucite, talc. No relict orthopyroxene grains were observed. Instead, reaction rims of secondary orthopyroxene around serpentinised 

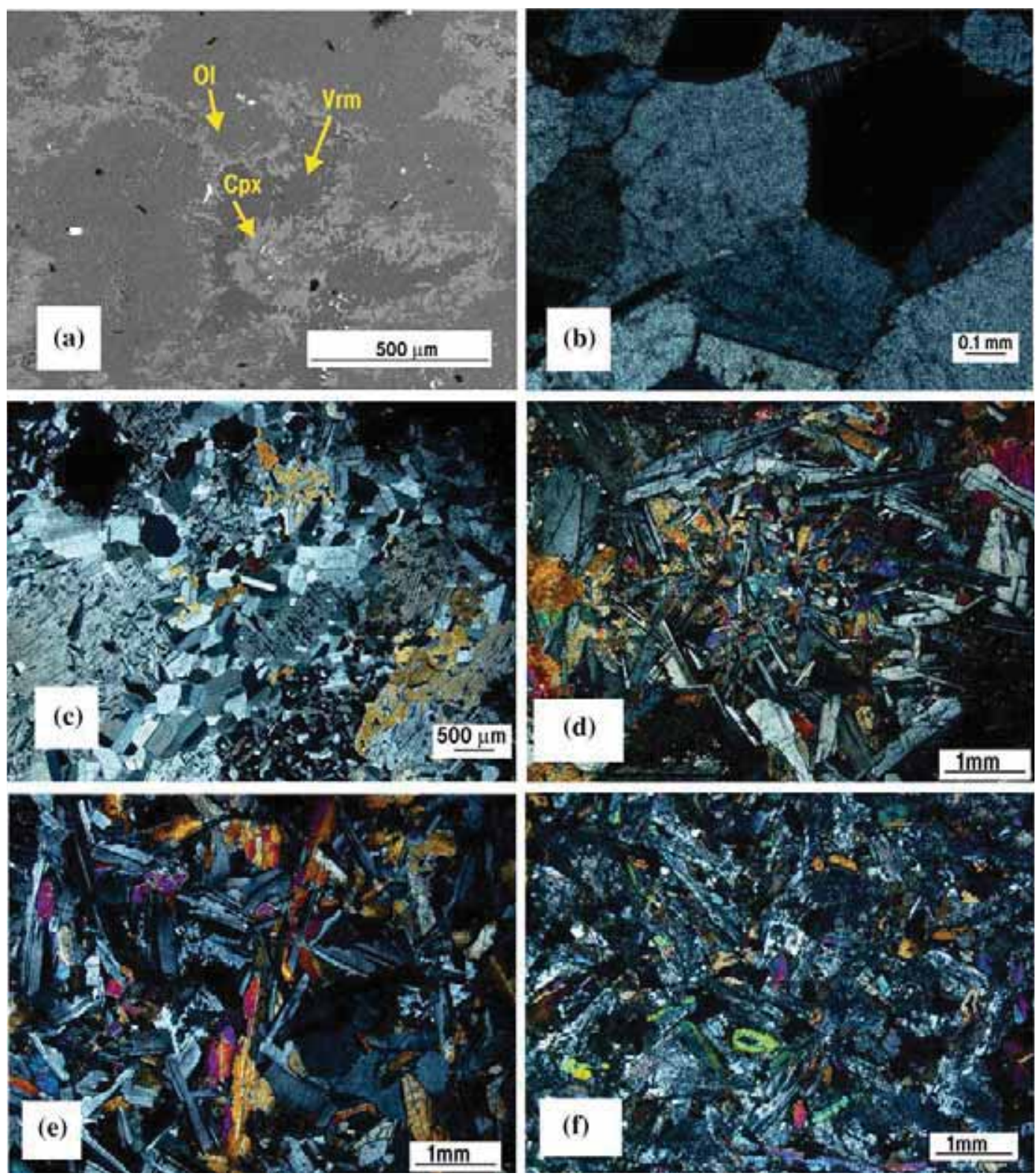

Figure 5. (a) Back-scattered electron image from BW showing reaction textures defined by rims of secondary clinopyroxene around serpentinised olivine, and vermiculite (low K phlogopite) in the interstices. (b) Photomicrograph under cross-polars showing cumulus texture defined by sub/euhedral plagioclase grains from the KLG unit. (c) Photomicrograph under cross-polars from KLG showing a poikilitic texture defined by inclusion-laden pyroxene grains and bi-modal size distribution of plagioclase. (d) Photomicrograph under cross-polars of the dolerite from North of Kuliana showing a bi-modal size distribution of plagioclase. (e) Photomicrograph under cross-polars showing the typical doleritic texture of mafic rocks from North of Kuliana. (f) Photomicrograph under cross-polars from mafic rocks of Jashipur showing the doleritic texture modified by hydrothermal alteration.

olivine grains were sometimes seen (figure $4 \mathrm{e}$ ). Olivine pseudomorphs, cross-cut by numerous serpentine veins with extensive magnetite crystallisation characterise the typical mesh-texture of serpentinised rocks (figure 4f). Clinopyroxene population consists of both relict primary grains and secondary grains. Often secondary clinopyroxene is found as a reaction rim around olivine pseudomorphs, with the vermiculite found in the interstices between these rimmed grains (figure 5a). Vermiculite, a low-K phlogopite, is a product of hydrothermal alteration from original phlogopite grains. It appears from overall petrography that the BW rocks have experienced another phase of alteration prior to the serpentinisation event. The KLG rocks on the other hand appear fresh and undeformed under a petrographic microscope. The primary constituents are plagioclase, clinopyroxene 
and orthopyroxene, with an accessory Cr-spinel. Ten isomodal layers were identified based on the modal proportions of plagioclase and pyroxene grains, and divided into two cycles based on repetitions. Adcumulate and poikilitic are the main textural varieties observed. The adcumulate textural variety is defined by large, zoning-free plagioclase, and large, inclusion-free, often exsolved pyroxene (figure 5b). Poikilitic texture is defined by pyroxene oikocrysts riddled with small plagioclase chadacrysts and relatively larger plagioclase as groundmass (figure 5c). This complex textural character of the KLG suite indicates the involvement of multiple processes during crystallisation.

Dolerites from North of Kuliana are medium to coarse rocks, having plagioclase, clinopyroxene and iron oxides as the primary constituent minerals. Plagioclase is present in two size modes: larger lath shaped, euhedral to subhedral grains and smaller subhedral to anhedral grains in the groundmass (figure 5d). Clinopyroxene grains are relatively smaller than plagioclase, subhedral to anhedral, and, in many cases, display simple/lamellar twinning. Fibrous hornblende (tremolite-actinolite) is present in these rocks as alteration products of primary clinopyroxene grains. The overall texture is characteristic of dolerite dykes because of the predominance of ophitic, sub-ophitic and intergranular textures (figure 5e). Smaller clinopyroxene occurs as inclusions within plagioclase in the groundmass suggesting that plagioclase crystallisation outlasted pyroxene nucleation from the melt. Variable hydrothermal alteration is manifested in the rocks by the presence of secondary hornblende. Most often, the alteration is restricted to the grain margins of the clinopyroxenes, but in extreme cases, replacement of almost the entire grain has been observed. The veins are made up of opaque phases and could be attributed to the process of hydrothermal alteration.

Dolerites of Jashipur have plagioclase and clinopyroxene as the principle mineral constituents, with overall medium grain size. Inequigranular textures are seen, along with sub-ophitic and intergranular texture (figure 5f). Plagioclase grains are all lath-shaped and have only one mode of occurrence. They appear clouded due to the crystallisation of fine-grained opaque phases during hydrothermal alteration. In a few instances, plagioclase laths appear folded/bent probably due to ductile deformation. Clinopyroxene grains are medium- to fine-grained and subhedral to anhedral. They often show twinning and are also in some case altered to fibrous amphiboles along grain margins. Fine, flaky biotites are seen in areas with relatively greater amounts of deformation. Iron oxides are mostly ilmenites and they have low modes of occurrence: relatively large, euhedral, prismatic grains probably of igneous origin, and smaller, anhedral grains mostly as inclusions formed during hydrothermal activity.

\section{Analytical techniques}

Selected thin-sections from the mafic rocks of Galudih, North of Bisoi and Jashipur were analysed to obtain major element chemistry of the constituent minerals. The electron probe micro analyser (EPMA) facility (Model: CAMECA SX100) of the Department of Geology and Geophysics, Indian Institute of Technology, Kharagpur (IIT-KGP) was used. The thin-sections were carbon-coated prior to EPMA in the facilities of the Department of Geology, Presidency University, Kolkata. Analyses were performed with a beam current of $15 \mathrm{nA}$ and an acceleration voltage of $15 \mathrm{kV}$. The dwell time was $10 \mathrm{~s}$ at the peak and $5 \mathrm{~s}$ for the background. The following standards and emission lines were used: jadeite $(\mathrm{Na}-\mathrm{K} \alpha 1$, $\mathrm{Si}-\mathrm{K} \alpha 1)$, diopside $(\mathrm{Ca}-\mathrm{K} \alpha 1, \mathrm{Mg}-\mathrm{K} \alpha 1)$, orthoclase (K-K $\alpha 1, \mathrm{Al}-\mathrm{K} \alpha 1)$, fluorapatite $(\mathrm{F}-\mathrm{K} \alpha 1, \mathrm{P}-\mathrm{K} \alpha 1)$, $\mathrm{NaCl}(\mathrm{Cl}-\mathrm{K} \alpha 1), \quad \mathrm{Fe}_{2} \mathrm{O}_{3} \quad(\mathrm{Fe}-\mathrm{K} \alpha 1), \quad$ rhodonite $(\mathrm{Mn}-\mathrm{K} \alpha 1)$ and $\mathrm{TiO}_{2}(\mathrm{Ti}-\mathrm{K} \alpha 1)$. A TAP crystal was used to analyse F, Na, Al, Si and Mg; PET for Ca, $\mathrm{Ti}, \mathrm{K}$ and $\mathrm{Cl}$; LPET for $\mathrm{P}$ and LIF for Mn and Fe. ZAF matrix corrections were performed based on the Cameca-supplied PAPSIL program. More analytical details can be found in Hazarika et al. (2015). Selected data are presented in table 2. EPMA data of KLG and BW were obtained from Chakraborti et al. (2016, 2017, 2018).

Whole rock major element composition of selected samples was analysed in the X-ray fluorescence facility (model: SIEMENS SRS 3000) of Wadia Institute of Himalayan Geology (WIHG), Dehradun, India. Trace elements, including rare earth concentrations, were determined in WIHG using the inductively coupled plasma mass spectrometer facility (model: PerkinElmer SCIEX ELANDRCe). The sample dissolution procedure of Khanna et al. (2009) was followed. International rock standards (JB-1a; basalt reference standard from the Geological Survey of Japan) were analysed along with the samples to check precision and accuracy. Analytical precision for the major elements is 
Table 2. Compositions of selected plagioclase and pyroxene from mafic rocks of Jashipur, North of Bisoi and Galudih.

\begin{tabular}{|c|c|c|c|c|c|c|c|c|c|c|c|c|}
\hline & \multicolumn{4}{|c|}{ Jashipur } & \multicolumn{4}{|c|}{ North of Bisoi } & \multicolumn{4}{|c|}{ Galudih } \\
\hline \multicolumn{13}{|c|}{ (a) Plagioclase } \\
\hline $\mathrm{SiO}_{2}$ & 51.9 & \multicolumn{2}{|c|}{52.8} & 52.6 & 55.3 & \multicolumn{2}{|c|}{53.3} & 55.2 & 49.7 & \multicolumn{2}{|c|}{52.2} & 52.1 \\
\hline $\mathrm{TiO}_{2}$ & 0.1 & \multicolumn{2}{|c|}{0.1} & 0.1 & 0.1 & \multicolumn{2}{|c|}{0.0} & 0.1 & 0.0 & \multicolumn{2}{|r|}{0.0} & 0.0 \\
\hline $\mathrm{Al}_{2} \mathrm{O}_{3}$ & 24.8 & \multicolumn{2}{|c|}{27.9} & 28.4 & 26.0 & \multicolumn{2}{|c|}{28.3} & 25.7 & 29.6 & \multicolumn{2}{|c|}{29.2} & 29.0 \\
\hline $\mathrm{Cr}_{2} \mathrm{O}_{3}$ & 0.0 & \multicolumn{2}{|c|}{0.0} & 0.0 & 0.0 & \multicolumn{2}{|c|}{0.0} & 0.0 & 0.0 & \multicolumn{2}{|r|}{0.0} & 0.0 \\
\hline $\mathrm{FeO}$ & 2.4 & 1. & & 1.0 & 0.7 & & & 0.6 & 0.7 & & 0.5 & 0.7 \\
\hline $\mathrm{MnO}$ & 0.1 & 0 . & & 0.0 & 0.0 & & & 0.0 & 0.0 & & 0.0 & 0.0 \\
\hline $\mathrm{MgO}$ & 0.0 & 0 . & & 0.1 & 0.1 & & & 0.1 & 0.1 & & 0.1 & 0.1 \\
\hline $\mathrm{CaO}$ & 13.8 & 12 . & & 12.4 & 9.4 & 12 & & 9.0 & 13.9 & & 3.1 & 13.5 \\
\hline $\mathrm{Na}_{2} \mathrm{O}$ & 5.5 & 4. & & 4.4 & 5.8 & & & 5.8 & 3.4 & & 4.1 & 4.0 \\
\hline $\mathrm{K}_{2} \mathrm{O}$ & 0.0 & 0 . & & 0.2 & 0.6 & & & 0.5 & 0.0 & & 0.1 & 0.1 \\
\hline Total & 98.5 & 98. & & 99.1 & 97.9 & 9 & & 97.1 & 97.5 & & 99.3 & 99.5 \\
\hline An & 57.7 & 59 . & & 60.2 & 45.7 & 58 & & 44.8 & 69.1 & & 33.5 & 64.6 \\
\hline $\mathrm{Ab}$ & 42.1 & 39. & & 38.9 & 51.1 & 3 & & 52.3 & 30.6 & & 35.8 & 34.8 \\
\hline Or & 0.2 & 1. & & 0.9 & 3.2 & & & 2.9 & 0.3 & & 0.7 & 0.6 \\
\hline Cation & calculated & on the bas & of 6 ox & ggen & & & & & & & & \\
\hline $\mathrm{Si}$ & 2.386 & & & 2.409 & 2.543 & & 436 & 2.559 & 2.326 & & 2.389 & 2.381 \\
\hline $\mathrm{Ti}$ & 0.002 & & & 0.003 & 0.003 & & 001 & 0.003 & 0.001 & & 0.000 & 0.000 \\
\hline $\mathrm{Al}$ & 1.343 & & & 1.533 & 1.408 & & 524 & 1.404 & 1.633 & & 1.576 & 1.560 \\
\hline $\mathrm{Cr}$ & 0.000 & & & 0.000 & 0.000 & & 000 & 0.001 & 0.000 & & 0.000 & 0.000 \\
\hline $\mathrm{Fe}^{+3}$ & 0.000 & & & 0.000 & 0.000 & & 000 & 0.000 & 0.000 & & 0.000 & 0.000 \\
\hline $\mathrm{Fe}^{+2}$ & 0.091 & & & 0.038 & 0.027 & & 020 & 0.025 & 0.026 & & 0.020 & 0.028 \\
\hline $\mathrm{Mn}$ & 0.002 & & & 0.001 & 0.000 & & 000 & 0.000 & 0.000 & & 0.000 & 0.001 \\
\hline $\mathrm{Mg}$ & 0.000 & & & 0.009 & 0.005 & & 006 & 0.005 & 0.006 & & 0.006 & 0.006 \\
\hline $\mathrm{Ca}$ & 0.678 & & & 0.608 & 0.464 & & 595 & 0.449 & 0.696 & & 0.640 & 0.661 \\
\hline $\mathrm{Na}$ & 0.495 & & & 0.392 & 0.518 & & 403 & 0.525 & 0.308 & & 0.360 & 0.356 \\
\hline$\underline{K}$ & 0.002 & & & 0.009 & 0.033 & & 015 & 0.029 & 0.003 & & 0.007 & 0.007 \\
\hline & & Jashi & & & & North & f Bisoi & & & $\mathrm{Ga}$ & ludih & \\
\hline (b) $\mathrm{Pyl}$ & rene & & & & & & & & & & & \\
\hline $\mathrm{SiO}_{2}$ & 51.58 & 50.72 & 49.92 & 50.83 & 51.96 & 54.17 & 52.00 & 51.36 & 52.83 & 51.65 & 50.70 & 49.06 \\
\hline $\mathrm{TiO}_{2}$ & 0.35 & 0.74 & 0.86 & 0.77 & 0.40 & 0.21 & 0.30 & 0.55 & 0.26 & 0.29 & 0.26 & 0.28 \\
\hline $\mathrm{Al}_{2} \mathrm{O}_{3}$ & 0.81 & 1.48 & 2.80 & 2.14 & 2.42 & 1.26 & 2.42 & 2.50 & 1.01 & 1.87 & 2.03 & 3.75 \\
\hline $\mathrm{Cr}_{2} \mathrm{O}_{3}$ & 0.00 & 0.04 & 0.15 & 0.04 & 0.55 & 0.20 & 0.49 & 0.61 & 0.02 & 0.03 & 0.05 & 0.00 \\
\hline $\mathrm{FeO}$ & 23.38 & 16.33 & 14.38 & 14.41 & 8.94 & 14.73 & 9.46 & 8.65 & 16.95 & 8.96 & 9.14 & 15.32 \\
\hline $\mathrm{MnO}$ & 0.55 & 0.42 & 0.30 & 0.36 & 0.19 & 0.24 & 0.19 & 0.17 & 0.37 & 0.21 & 0.24 & 0.26 \\
\hline $\mathrm{MgO}$ & 18.31 & 13.66 & 13.70 & 16.12 & 16.52 & 26.83 & 18.04 & 15.29 & 23.18 & 17.24 & 14.29 & 14.70 \\
\hline $\mathrm{CaO}$ & 4.95 & 16.62 & 17.38 & 14.84 & 17.88 & 2.26 & 16.52 & 19.67 & 3.88 & 17.35 & 20.26 & 14.82 \\
\hline $\mathrm{Na}_{2} \mathrm{O}$ & 0.09 & 0.23 & 0.21 & 0.19 & 0.48 & 0.03 & 0.42 & 0.45 & 0.05 & 0.21 & 0.21 & 0.19 \\
\hline Total & 100.01 & 100.24 & 99.71 & 99.69 & 99.33 & 99.94 & 99.84 & 99.25 & 98.54 & 97.82 & 97.16 & 98.37 \\
\hline Wo & 10.2 & 34.4 & 36.5 & 30.6 & 37.4 & 4.4 & 33.7 & 41.2 & 7.9 & 35.9 & 42.9 & 31.4 \\
\hline En & 52.3 & 39.3 & 40.0 & 46.2 & 48.0 & 73.1 & 51.2 & 44.6 & 65.3 & 49.6 & 42.1 & 43.3 \\
\hline Fs & 37.5 & 26.4 & 23.6 & 23.2 & 14.6 & 22.5 & 15.1 & 14.2 & 26.8 & 14.5 & 15.1 & 25.3 \\
\hline Cation & calculated & on the bas & of 6 ox & gen & & & & & & & & \\
\hline $\mathrm{Si}$ & 1.954 & 1.920 & 1.889 & 1.907 & 1.926 & 1.953 & 1.909 & 1.914 & 1.966 & 1.940 & 1.940 & 1.871 \\
\hline $\mathrm{Ti}$ & 0.010 & 0.021 & 0.025 & 0.022 & 0.011 & 0.006 & 0.008 & 0.016 & 0.007 & 0.008 & 0.007 & 0.008 \\
\hline $\mathrm{Al}$ & 0.036 & 0.066 & 0.125 & 0.094 & 0.106 & 0.054 & 0.105 & 0.110 & 0.044 & 0.083 & 0.091 & 0.168 \\
\hline $\mathrm{Cr}$ & 0.000 & 0.001 & 0.005 & 0.001 & 0.016 & 0.006 & 0.014 & 0.018 & 0.000 & 0.001 & 0.001 & 0.000 \\
\hline $\mathrm{Fe}^{+3}$ & 0.043 & 0.068 & 0.059 & 0.061 & 0.037 & 0.027 & 0.076 & 0.046 & 0.012 & 0.035 & 0.029 & 0.087 \\
\hline $\mathrm{Fe}^{+2}$ & 0.698 & 0.449 & 0.396 & 0.392 & 0.240 & 0.417 & 0.214 & 0.224 & 0.515 & 0.247 & 0.264 & 0.402 \\
\hline $\mathrm{Mn}$ & 0.018 & 0.013 & 0.010 & 0.012 & 0.006 & 0.007 & 0.006 & 0.005 & 0.012 & 0.007 & 0.008 & 0.008 \\
\hline $\mathrm{Mg}$ & 1.034 & 0.771 & 0.773 & 0.902 & 0.913 & 1.442 & 0.987 & 0.849 & 1.285 & 0.966 & 0.815 & 0.836 \\
\hline $\mathrm{Ca}$ & 0.201 & 0.674 & 0.704 & 0.596 & 0.710 & 0.087 & 0.650 & 0.785 & 0.155 & 0.698 & 0.830 & 0.606 \\
\hline $\mathrm{Na}$ & 0.007 & 0.017 & 0.016 & 0.014 & 0.034 & 0.002 & 0.030 & 0.033 & 0.003 & 0.015 & 0.015 & 0.014 \\
\hline
\end{tabular}


within $\pm 2-3 \%$ and for trace elements is within $\pm 5-6 \%$. Accuracy of REE analyses ranges from 2 to $12 \%$ and precision varies from 1 to $8 \%$ (Khanna et al. 2009). The whole rock geochemical data are presented in table 3. Whole-rock data of KLG and BW were obtained from Chakraborti et al. (2016, 2018).

\section{Mineralogy}

The plagioclase grains from the gabbroic rocks of Galudih show a restricted range $\left(\mathrm{An}_{56}-\mathrm{An}_{67}\right)$ of composition, falling in the labradorite field (figure 6a). They have slightly variable $\mathrm{K}_{2} \mathrm{O}$ contents of 0.04-1.03 wt\%. Clinopyroxenes have relatively larger compositional variability with augite, ferroaugite and magnesian pigeonite types being present (figure 6b). They have very low $\mathrm{Na}_{2} \mathrm{O}$ $(<0.24$ wt $\%)$, moderately variable $\mathrm{Cr}_{2} \mathrm{O}_{3}(0.02-0.11$ wt\%) and highly variable $\mathrm{TiO}_{2}(0.06-0.46 \mathrm{wt} \%)$. The $\mathrm{Mg} \#\left(100 * \mathrm{Mg} / \mathrm{Mg}+\mathrm{Fe}^{+2}\right)$ range of the calculated clinopyroxenes is $50-80$ with an average of 73. High-MnO (>1.8 wt\%) ilmenites are the only iron oxide phase found. Pressure estimates were calculated with the 'CpxBar' Microsoft Excel program of Nimis and Ulmer (1998) which yielded $\sim 0.8$ Gpa. As this geobarometer is optimised for undeformed mafic volcanic rocks, the calculated pressure estimates of the multiply deformed rocks of Galudih probably reflect the pressures of the last deformation episode.

Mineralogical data of dolerites from North of Bisoi are from the coarse-grained dolerite dyke with a bi-modal size distribution of plagioclase. Plagioclase grains exhibit two compositional varieties from andesine $\left(\mathrm{An}_{45}-\mathrm{An}_{47}\right)$ to labradorite $\left(\mathrm{An}_{51}-\mathrm{An}_{59}\right)$ (figure 6a). The relatively smaller plagioclase grains occurring as inclusions within larger plagioclase grains have higher $\mathrm{CaO}$, reflecting formation under higher temperature. A few alkali feldspar grains of sanidine variety $\left(\mathrm{Or}_{37}\right)$ are also encountered. All analysed clinopyroxene grains are augite with compositional range of $\mathrm{Wo}_{34-42} \mathrm{En}_{44-51} \mathrm{Fs}_{13-17}$ (figure 6b). These clinopyroxene grains have low $\mathrm{Na}_{2} \mathrm{O}(<0.64 \mathrm{wt} \%)$, and moderate $\mathrm{Al}_{2} \mathrm{O}_{3}(1.42-2.5$ wt $\%), \mathrm{Cr}_{2} \mathrm{O}_{3}(<0.6 \mathrm{wt} \%)$ and $\mathrm{TiO}_{2}(<0.7 \mathrm{wt} \%)$. CrSpinels with $\mathrm{Cr} \#(100 * \mathrm{Cr} / \mathrm{Cr}+\mathrm{Al})$ of $\sim 60$ are sometimes seen as inclusions within the clinopyroxene. Orthopyroxene grains of bronzite variety are also observed with a compositional range of $\mathrm{Wo}_{4} \mathrm{En}_{73-79} \mathrm{Fs}_{17-22}$. Both types of pyroxene have relatively high $\mathrm{Mg} \#$ in the range of 76-83. Using the
CpxBar program, these clinopyroxene grains give pressure estimates of 1.0-1.3 Gpa. As the coarsegrained mafic dykes show little evidence of hydrothermal alteration, the calculated pressures can be said to reflect magmatic conditions. From the coexisting magnetite-ilmenite pair, the $\mathrm{Fe}-\mathrm{Ti}$ exchange temperature was calculated (Ghiorso and Evans 2008 ) to be $\sim 400^{\circ} \mathrm{C}$. This temperature probably reflects the shallow level hydrothermal alteration process during which the magnetite grain formed.

Most of the serpentine grains from BW have $\mathrm{Mg}$ \# ranging from 80 to 86 with a few values as low as 72-73. XRD analysis revealed that the predominant species of serpentine present are antigorite and lizardite, with minor occurrences of chrysotile. Clinopyroxene grain population consists of two species (figure 6b): augite (more abundant) with a compositional range of $\mathrm{Wo}_{24-28} \mathrm{En}_{62-68} \mathrm{Fs}_{4-11}$ and diopside with a compositional range of $\mathrm{Wo}_{41-44} \mathrm{En}_{47-51} \mathrm{Fs}_{7-8}$. The $\mathrm{Mg} \#$ of augite grains ranges between 76 and 93 and relatively higher (86-93) for diopside grains. Augite grains are usually secondary in nature, having lower $\mathrm{Cr}, \mathrm{Ti}, \mathrm{Ca} /$ $\mathrm{Mg}$ values than the diopside, which are considered to be the relict primary grains. Cr-Spinels have high Cr\# (77-92) and have outer magnetite mantles formed during serpentinisation. Vermiculites have low $\mathrm{K}_{2} \mathrm{O}$ and $\mathrm{Mg} \#$ ranges of 74-82. Secondary orthopyroxene occurs only as rims around serpentinised olivine and have bronzitic composition and low Mg\# (62-63). In KLG rocks, plagioclase has a composition of $\mathrm{An}_{57-66}$ in adcumulate textural variety, with diopside and augite similar in composition with BW (figure 6a and b). Plagioclase inclusions and groundmass grains have uniform compositions $\left(\mathrm{An}_{76-85}\right)$ in the poikilitic textural type. Orthopyroxene in KLG rocks occurs as distinct grains and is bronzitic type. Layer-wise variation of mineral composition revealed that the minerals shift to more primitive compositions in the middle part of cycle I, which suggests a possible magma chamber influx event (for more details, see Chakraborti et al. 2016). P-T calculations of the KLG suite yields temperatures of $990^{\circ} \mathrm{C}$ and 1.3-1.4 Gpa pressure (Chakraborti et al. 2017), whereas the pressure estimates of BW are higher at 3.5-4.8 Gpa with the calculated temperature from 1036 to $1146^{\circ} \mathrm{C}$ (Chakraborti 2018).

Dolerites from North of Kuliana have andesineand labradorite-type plagioclase grains, showing high-compositional variability $\left(\mathrm{An}_{36}-\mathrm{An}_{58}\right)$ (figure 6a). Clinopyroxenes fall in the augite and magnesian pigeonite compositional fields 
Table 3. Whole-rock major, trace elements of mafic rocks from North of Kuliana, Galudih, Jashipur, and North of Bisoi.

\begin{tabular}{|c|c|c|c|c|c|c|c|c|c|c|c|c|}
\hline \multirow[b]{2}{*}{ Sample no. } & \multicolumn{6}{|c|}{ North of Kuliana } & \multicolumn{6}{|c|}{ Galudih } \\
\hline & B12 & B12A & B15 & B16 & B40 & B42 & G1 & $\mathrm{G} 2 \mathrm{~B}$ & G6 & G8 & G10 & G12 \\
\hline $\mathrm{SiO}_{2}$ & 51.04 & 48.25 & 47.96 & 48.03 & 51.21 & 49.67 & 50.86 & 47.65 & 51.11 & 50.96 & 50.85 & 51.25 \\
\hline $\mathrm{Al}_{2} \mathrm{O}_{3}$ & 15.17 & 14.14 & 14.19 & 14.51 & 12.93 & 12.58 & 12.76 & 14.39 & 15.01 & 13.60 & 13.64 & 14.34 \\
\hline $\mathrm{MgO}$ & 7.53 & 6.08 & 6.55 & 6.68 & 9.06 & 9.84 & 7.53 & 7.29 & 5.17 & 6.49 & 8.38 & 5.84 \\
\hline $\mathrm{Na}_{2} \mathrm{O}$ & 2.04 & 2.49 & 2.34 & 2.37 & 1.47 & 1.36 & 2.30 & 2.55 & 2.91 & 2.64 & 2.34 & 2.73 \\
\hline $\mathrm{P}_{2} \mathrm{O}_{5}$ & 0.10 & 0.14 & 0.15 & 0.14 & 0.05 & 0.07 & 0.11 & 0.12 & 0.16 & 0.13 & 0.09 & 0.14 \\
\hline $\mathrm{K}_{2} \mathrm{O}$ & 0.33 & 0.23 & 0.25 & 0.24 & 0.54 & 0.54 & 0.84 & 0.74 & 0.66 & 0.96 & 0.35 & 0.80 \\
\hline $\mathrm{CaO}$ & 11.42 & 11.10 & 11.59 & 11.70 & 11.58 & 12.14 & 9.83 & 10.17 & 9.53 & 9.50 & 10.56 & 9.69 \\
\hline $\mathrm{TiO}_{2}$ & 0.86 & 1.48 & 1.50 & 1.41 & 0.61 & 0.69 & 0.92 & 1.10 & 1.13 & 1.02 & 0.75 & 0.99 \\
\hline $\mathrm{MnO}$ & 0.17 & 0.23 & 0.21 & 0.21 & 0.18 & 0.16 & 0.16 & 0.19 & 0.15 & 0.16 & 0.15 & 0.15 \\
\hline Total $\mathrm{Fe}_{2} \mathrm{O}_{3}$ & 11.55 & 15.78 & 14.80 & 14.10 & 10.38 & 10.47 & 12.21 & 13.96 & 12.55 & 12.51 & 11.13 & 12.35 \\
\hline Total & 100.21 & 99.92 & 99.54 & 99.39 & 98.01 & 97.52 & 97.52 & 98.16 & 98.38 & 97.97 & 98.24 & 98.28 \\
\hline LOI & 0.30 & 0.56 & 0.08 & 0.11 & 0.99 & 0.71 & 1.89 & 2.33 & 1.55 & 1.99 & 2.12 & 1.91 \\
\hline $\mathrm{Mg} \#$ & 47.52 & 34.86 & 38.07 & 39.69 & 54.80 & 56.62 & 46.14 & 42.04 & 36.39 & 41.88 & 51.12 & 39.64 \\
\hline $\mathrm{Cr}$ & 156.00 & 167.00 & 212.00 & 210.00 & 235.00 & 353.00 & 267.00 & 96.00 & 70.00 & 116.00 & 119.00 & 81.00 \\
\hline $\mathrm{Zr}$ & 56.00 & 80.00 & 85.00 & 77.00 & 32.00 & 45.00 & 63.00 & 77.00 & 85.00 & 75.00 & 46.00 & 68.00 \\
\hline $\mathrm{Ba}$ & 100.00 & 80.00 & 68.00 & 65.00 & 129.00 & 133.00 & 75.00 & 135.00 & 141.00 & 136.00 & 222.00 & 170.00 \\
\hline $\mathrm{Co}$ & 85.60 & 103.00 & 67.00 & 67.40 & 70.50 & 81.50 & 57.80 & 60.80 & 59.30 & 69.20 & 60.50 & 81.20 \\
\hline $\mathrm{Cu}$ & 67.00 & 108.00 & 109.00 & 103.00 & 69.00 & 79.00 & 93.00 & 117.00 & 97.00 & 107.00 & 116.00 & 117.00 \\
\hline $\mathrm{Ga}$ & 12.00 & 35.00 & 11.00 & 11.00 & 14.00 & 12.00 & 11.00 & 14.00 & 13.00 & 15.00 & 16.00 & 16.00 \\
\hline $\mathrm{Nb}$ & 4.30 & 5.30 & 4.80 & 5.50 & 1.90 & 7.30 & 3.20 & 4.50 & 4.40 & 7.40 & 5.80 & 4.30 \\
\hline $\mathrm{Ni}$ & 99.00 & 85.00 & 100.00 & 89.00 & 93.00 & 151.00 & 107.00 & 113.00 & 96.00 & 88.00 & 95.00 & 107.00 \\
\hline $\mathrm{Pb}$ & 3.30 & 5.00 & 1.30 & 0.80 & 11.00 & 6.70 & 1.80 & 1.90 & 0.90 & 1.00 & 4.00 & 2.40 \\
\hline $\mathrm{Rb}$ & 10.80 & 24.80 & 4.60 & 5.30 & 18.50 & 14.10 & 9.50 & 21.60 & 24.90 & 16.60 & 12.70 & 22.50 \\
\hline $\mathrm{Sc}$ & 41.60 & 57.80 & 51.00 & 50.80 & 42.00 & 46.30 & 30.10 & 31.40 & 29.50 & 28.50 & 38.50 & 30.60 \\
\hline $\mathrm{Sr}$ & 141.00 & 127.00 & 116.00 & 115.00 & 126.00 & 119.00 & 176.00 & 190.00 & 195.00 & 202.00 & 169.00 & 191.00 \\
\hline Th & 1.10 & 0.80 & 0.90 & 0.80 & 0.90 & 1.00 & 1.00 & 1.40 & 1.60 & 2.00 & 1.40 & 1.60 \\
\hline $\mathrm{V}$ & 209.00 & 563.00 & 259.00 & 259.00 & 203.00 & 206.00 & 176.00 & 212.00 & 192.00 & 214.00 & 230.00 & 202.00 \\
\hline $\mathrm{Y}$ & 18.00 & 28.00 & 29.00 & 27.00 & 15.00 & 16.00 & 13.00 & 17.00 & 18.00 & 20.00 & 22.00 & 19.00 \\
\hline $\mathrm{Zn}$ & 80.00 & 121.00 & 60.00 & 59.00 & 68.00 & 69.00 & 58.00 & 73.00 & 74.00 & 75.00 & 86.00 & 79.00 \\
\hline $\mathrm{U}$ & 0.30 & 0.20 & 0.20 & 0.20 & 0.30 & 0.30 & 0.30 & 0.40 & 0.50 & 0.60 & 0.30 & 0.50 \\
\hline $\mathrm{La}$ & 7.00 & 6.50 & 6.60 & 6.20 & 4.60 & 6.80 & 6.00 & 8.60 & 9.60 & 11.10 & 8.10 & 10.30 \\
\hline $\mathrm{Ce}$ & 15.30 & 16.10 & 16.10 & 14.70 & 9.50 & 14.50 & 12.70 & 18.30 & 20.30 & 23.70 & 18.00 & 22.10 \\
\hline $\operatorname{Pr}$ & 2.10 & 2.50 & 2.40 & 2.30 & 1.30 & 1.90 & 1.70 & 2.40 & 2.70 & 3.10 & 2.50 & 3.00 \\
\hline $\mathrm{Nd}$ & 9.10 & 11.60 & 11.30 & 10.40 & 5.80 & 8.00 & 7.40 & 10.00 & 10.90 & 12.70 & 10.60 & 12.20 \\
\hline $\mathrm{Sm}$ & 2.30 & 3.55 & 3.38 & 3.14 & 1.62 & 2.05 & 1.86 & 2.49 & 2.76 & 3.12 & 2.83 & 3.00 \\
\hline $\mathrm{Eu}$ & 0.83 & 1.30 & 1.18 & 1.11 & 0.66 & 0.74 & 0.73 & 0.87 & 0.96 & 1.05 & 1.09 & 1.07 \\
\hline $\mathrm{Gd}$ & 2.74 & 4.53 & 4.30 & 3.95 & 2.03 & 2.47 & 2.19 & 2.88 & 3.20 & 3.60 & 3.47 & 3.54 \\
\hline $\mathrm{Tb}$ & 0.49 & 0.83 & 0.77 & 0.72 & 0.37 & 0.43 & 0.37 & 0.48 & 0.53 & 0.59 & 0.59 & 0.57 \\
\hline Dy & 3.04 & 5.57 & 4.94 & 4.66 & 2.41 & 2.72 & 2.31 & 2.87 & 3.25 & 3.56 & 3.79 & 3.49 \\
\hline Но & 0.69 & 1.21 & 1.10 & 1.03 & 0.55 & 0.60 & 0.50 & 0.62 & 0.70 & 0.78 & 0.83 & 0.74 \\
\hline Er & 1.84 & 3.33 & 2.96 & 2.75 & 1.49 & 1.62 & 1.31 & 1.64 & 1.79 & 2.04 & 2.21 & 1.99 \\
\hline $\mathrm{Tm}$ & 0.29 & 0.52 & 0.46 & 0.42 & 0.24 & 0.25 & 0.20 & 0.24 & 0.28 & 0.31 & 0.34 & 0.30 \\
\hline $\mathrm{Yb}$ & 1.89 & 3.35 & 3.03 & 2.80 & 1.57 & 1.70 & 1.29 & 1.61 & 1.80 & 2.02 & 2.19 & 1.95 \\
\hline $\mathrm{Lu}$ & 0.29 & 0.52 & 0.46 & 0.43 & 0.24 & 0.26 & 0.20 & 0.25 & 0.28 & 0.31 & 0.34 & 0.30 \\
\hline $\mathrm{Eu} / \mathrm{Eu}^{* 1}$ & 1.01 & 0.99 & 0.95 & 0.96 & 1.11 & 1.00 & 1.10 & 0.99 & 0.99 & 0.96 & 1.06 & 1.00 \\
\hline$(\mathrm{La} / \mathrm{Yb})_{N}^{2}$ & 2.50 & 1.31 & 1.47 & 1.49 & 1.98 & 2.70 & 3.14 & 3.60 & 3.60 & 3.70 & 2.49 & 3.56 \\
\hline$\Sigma \mathrm{REE}$ & 47.90 & 61.41 & 58.98 & 54.61 & 32.38 & 44.04 & 38.76 & 53.25 & 59.05 & 67.98 & 56.88 & 64.55 \\
\hline
\end{tabular}


Table 3. (Continued.)

\begin{tabular}{|c|c|c|c|c|c|c|c|c|c|c|}
\hline \multirow[b]{2}{*}{ Sample no. } & \multicolumn{4}{|c|}{ Jashipur } & \multicolumn{6}{|c|}{ North of Bisoi } \\
\hline & L125 & L126 & L129 & L130A & L90 & L91(1) & L91A & L92 & L93(1) & L94 \\
\hline $\mathrm{SiO}_{2}$ & 47.24 & 47.18 & 47.88 & 45.57 & 52.52 & 53.41 & 53.61 & 46.31 & 50.49 & 52.91 \\
\hline $\mathrm{Al}_{2} \mathrm{O}_{3}$ & 11.52 & 11.81 & 10.75 & 8.96 & 7.87 & 10.15 & 10.39 & 6.02 & 12.13 & 10.46 \\
\hline $\mathrm{MgO}$ & 6.24 & 5.33 & 13.73 & 13.93 & 16.52 & 12.47 & 11.29 & 22.50 & 10.51 & 11.12 \\
\hline $\mathrm{Na}_{2} \mathrm{O}$ & 2.42 & 2.51 & 1.57 & 1.81 & 1.57 & 2.39 & 2.32 & 0.36 & 1.62 & 1.73 \\
\hline $\mathrm{P}_{2} \mathrm{O}_{5}$ & 0.86 & 0.81 & 0.14 & 0.12 & 0.07 & 0.10 & 0.11 & 0.06 & 0.07 & 0.10 \\
\hline $\mathrm{K}_{2} \mathrm{O}$ & 0.84 & 0.91 & 1.47 & 0.30 & 0.36 & 0.75 & 1.00 & 0.17 & 1.04 & 1.35 \\
\hline $\mathrm{CaO}$ & 8.89 & 8.98 & 7.08 & 7.61 & 9.09 & 6.43 & 6.78 & 7.00 & 11.06 & 7.40 \\
\hline $\mathrm{TiO}_{2}$ & 2.88 & 2.86 & 1.44 & 1.78 & 0.62 & 1.05 & 1.08 & 0.78 & 0.74 & 0.97 \\
\hline $\mathrm{MnO}$ & 0.23 & 0.23 & 0.16 & 0.22 & 0.17 & 0.16 & 0.16 & 0.22 & 0.15 & 0.15 \\
\hline Total $\mathrm{Fe}_{2} \mathrm{O}_{3}$ & 18.29 & 18.68 & 12.87 & 15.89 & 10.33 & 12.47 & 12.67 & 14.07 & 10.94 & 12.36 \\
\hline Total & 99.41 & 99.30 & 97.09 & 96.19 & 99.12 & 99.38 & 99.41 & 97.49 & 98.75 & 98.55 \\
\hline LOI & 1.29 & 1.37 & 3.52 & 3.39 & 0.74 & 1.10 & 0.90 & 2.38 & 1.59 & 1.70 \\
\hline $\mathrm{Mg} \#$ & 32.15 & 28.38 & 59.70 & 54.91 & 68.96 & 58.14 & 55.31 & 68.95 & 57.16 & 55.55 \\
\hline $\mathrm{Cr}$ & 64.00 & 75.00 & 625.00 & 710.00 & 2469.00 & 1041.00 & 1004.00 & 1574.00 & 364.00 & 877.00 \\
\hline $\mathrm{Zr}$ & 236.00 & 217.00 & 128.00 & 153.00 & 109.00 & 174.00 & 172.00 & 110.00 & 62.00 & 153.00 \\
\hline $\mathrm{Ba}$ & 254.00 & 214.00 & 211.00 & 59.00 & 97.00 & 232.00 & 275.00 & 19.00 & 168.00 & 229.00 \\
\hline $\mathrm{Co}$ & 76.70 & 75.20 & 75.00 & 83.30 & 90.00 & 74.00 & 78.00 & 122.00 & 63.50 & 68.10 \\
\hline $\mathrm{Cu}$ & 149.00 & 85.00 & 78.00 & 125.00 & 155.00 & 121.00 & 129.00 & 100.00 & 254.00 & 114.00 \\
\hline $\mathrm{Ga}$ & 19.00 & 17.00 & 18.00 & 12.00 & 10.20 & 16.70 & 19.00 & 11.20 & 14.60 & 16.90 \\
\hline $\mathrm{Nb}$ & 4.00 & 13.80 & 16.60 & 6.00 & 3.50 & 9.50 & 9.30 & 2.10 & 3.90 & 7.00 \\
\hline $\mathrm{Ni}$ & 325.00 & 115.00 & 96.00 & 847.00 & 410.00 & 280.00 & 286.00 & 515.00 & 191.00 & 225.00 \\
\hline $\mathrm{Pb}$ & 9.70 & 5.00 & 1.80 & 0.90 & 3.20 & 6.20 & 6.50 & 4.20 & 4.70 & 13.20 \\
\hline $\mathrm{Rb}$ & 46.00 & 30.50 & 27.40 & 14.70 & 11.00 & 40.00 & 44.60 & 6.80 & 62.30 & 68.00 \\
\hline $\mathrm{Sc}$ & 24.90 & 35.30 & 34.70 & 26.40 & 35.50 & 22.00 & 24.70 & 25.20 & 45.50 & 24.40 \\
\hline $\mathrm{Sr}$ & 182.00 & 125.00 & 131.00 & 49.00 & 137.00 & 173.00 & 186.00 & 24.00 & 131.00 & 159.00 \\
\hline Th & 2.20 & 3.10 & 3.40 & 2.30 & 0.73 & 5.80 & 6.10 & 1.53 & 1.92 & 5.32 \\
\hline $\mathrm{V}$ & 241.00 & 327.00 & 318.00 & 255.00 & 171.00 & 186.00 & 212.00 & 171.00 & 229.00 & 183.00 \\
\hline $\mathrm{Y}$ & 20.00 & 49.00 & 54.00 & 22.00 & 12.50 & 21.00 & 23.00 & 16.00 & 18.70 & 20.50 \\
\hline $\mathrm{Zn}$ & 103.00 & 158.00 & 164.00 & 66.30 & 43.40 & 58.00 & 61.00 & 54.00 & 54.30 & 56.00 \\
\hline $\mathrm{U}$ & 0.60 & 0.90 & 1.00 & 0.60 & 0.21 & 1.96 & 2.10 & 0.35 & 0.58 & 1.96 \\
\hline $\mathrm{La}$ & 10.60 & 23.10 & 25.10 & 10.90 & 6.90 & 20.60 & 21.30 & 19.70 & 7.70 & 7.00 \\
\hline $\mathrm{Ce}$ & 24.30 & 52.50 & 56.90 & 24.60 & 14.60 & 42.20 & 44.00 & 40.60 & 15.40 & 14.80 \\
\hline $\mathrm{Pr}$ & 3.40 & 7.20 & 7.70 & 3.50 & 2.00 & 5.30 & 5.40 & 5.10 & 1.90 & 2.00 \\
\hline $\mathrm{Nd}$ & 14.80 & 31.30 & 33.40 & 15.80 & 8.20 & 20.20 & 21.00 & 19.50 & 7.60 & 8.40 \\
\hline $\mathrm{Sm}$ & 4.01 & 7.68 & 8.10 & 4.40 & 2.03 & 4.33 & 4.49 & 4.24 & 2.04 & 2.25 \\
\hline $\mathrm{Eu}$ & 1.34 & 2.36 & 2.43 & 1.37 & 0.69 & 1.18 & 1.22 & 1.19 & 0.70 & 0.79 \\
\hline Gd & 4.45 & 8.97 & 9.34 & 4.84 & 2.30 & 4.69 & 4.74 & 4.50 & 2.54 & 2.67 \\
\hline $\mathrm{Tb}$ & 0.71 & 1.45 & 1.52 & 0.76 & 0.37 & 0.69 & 0.72 & 0.68 & 0.44 & 0.46 \\
\hline Dy & 4.09 & 8.88 & 9.17 & 4.41 & 2.07 & 3.78 & 3.94 & 3.74 & 2.70 & 2.91 \\
\hline Но & 0.82 & 1.94 & 1.99 & 0.86 & 0.43 & 0.76 & 0.79 & 0.73 & 0.56 & 0.65 \\
\hline Er & 1.99 & 5.08 & 5.33 & 2.08 & 1.15 & 1.98 & 2.07 & 1.93 & 1.43 & 1.71 \\
\hline $\mathrm{Tm}$ & 0.28 & 0.79 & 0.81 & 0.29 & 0.17 & 0.29 & 0.31 & 0.28 & 0.21 & 0.27 \\
\hline $\mathrm{Yb}$ & 1.77 & 5.01 & 5.29 & 1.81 & 1.10 & 1.93 & 1.94 & 1.87 & 1.36 & 1.76 \\
\hline $\mathrm{Lu}$ & 0.26 & 0.77 & 0.81 & 0.26 & 0.16 & 0.28 & 0.29 & 0.28 & 0.20 & 0.27 \\
\hline $\mathrm{Eu} / \mathrm{Eu}^{* 1}$ & 0.97 & 0.87 & 0.85 & 0.90 & 0.97 & 0.80 & 0.80 & 0.83 & 0.94 & 0.98 \\
\hline$(\mathrm{La} / \mathrm{Yb})_{N}^{2}$ & 4.04 & 3.11 & 3.20 & 4.06 & 4.23 & 7.20 & 7.40 & 7.10 & 3.82 & 2.68 \\
\hline$\Sigma$ REE & 72.82 & 157.03 & 167.89 & 75.88 & 42.17 & 108.21 & 112.21 & 104.34 & 44.78 & 45.94 \\
\hline
\end{tabular}

${ }_{1} \mathrm{Eu} / \mathrm{Eu}^{*}=\mathrm{Eu}_{N} /\left(\mathrm{Sm}_{N}+\mathrm{Gd}_{N}\right) ;$ normalising values taken from Boynton (1984).

2 Normalising values taken from Boynton (1984). 
(a)

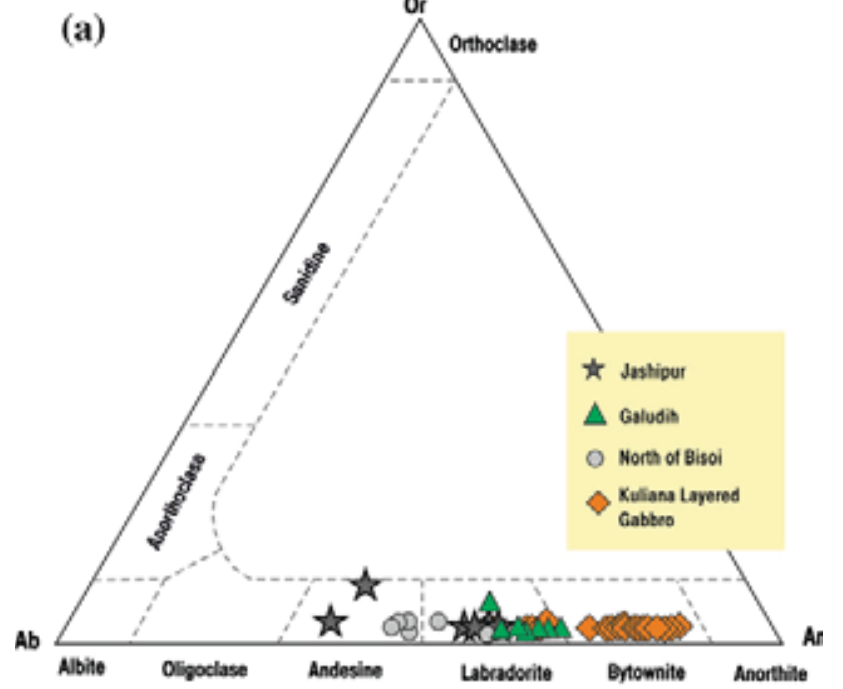

(b)

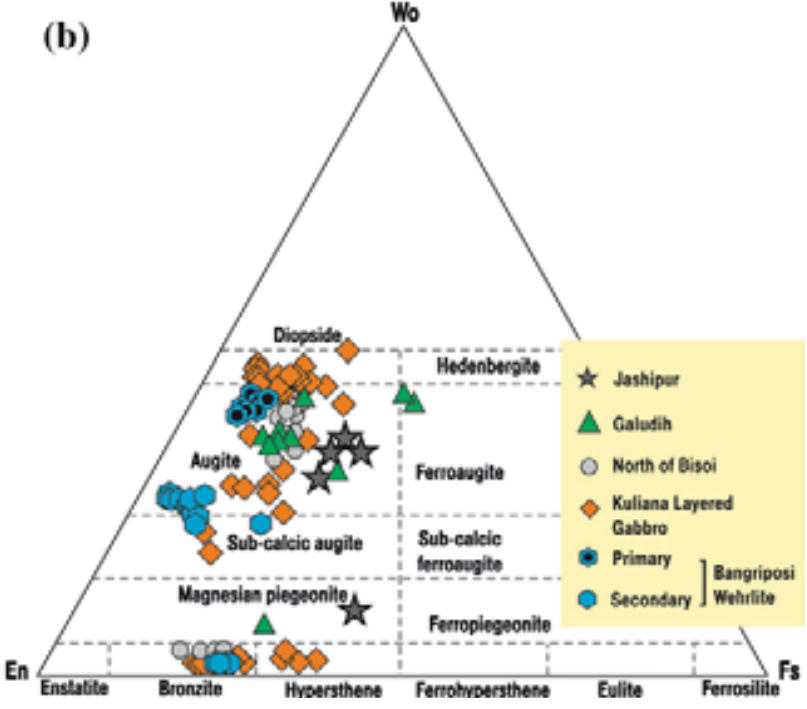

Figure 6. (a) Plagioclase end-member diagram showing plots of grains from mafic rocks of Jashipur, North of Bisoi, Galudih and KLG. (b) End-member diagram of pyroxene showing plots of grains from mafic-ultramafic rocks of Jashipur, North of Bisoi, Galudih, KLG and BW. The data of KLG and BW are taken from Chakraborti et al. (2016, 2017, 2018).

(figure 6b), with a range of $\mathrm{Wo}_{10-36} \mathrm{En}_{39-52} \mathrm{Fs}_{22-37}$. This variability can be attributed to the effect of deformation and hydrothermal alteration. $\mathrm{Mg} \#$ of the clinopyroxene is in the range of 60-70, and they have relatively higher $\mathrm{TiO}_{2}(<0.86 \mathrm{wt} \%)$, variable $\mathrm{Al}_{2} \mathrm{O}_{3}\left(0.8-2.8\right.$ wt\%) with very low $\mathrm{Na}_{2} \mathrm{O}(<0.26$ wt\%) and $\mathrm{Cr}_{2} \mathrm{O}_{3}(<0.15 \mathrm{wt} \%)$. Ilmenite grains also exhibit variability in terms of $\mathrm{TiO}_{2}$ concentrations (18-50 wt\%). Analysed biotite grains have relatively high $\mathrm{Fe} *\left(100 * \mathrm{Fe}^{+2} / \mathrm{Fe}^{+2}+\mathrm{Mg}\right)$ values of 75 . $\mathrm{Fe}-\mathrm{Mg}$ exchange temperatures were calculated (Luhr et al. 1984) from biotite compositions, and the results are in the range of $880-890^{\circ} \mathrm{C}$. None

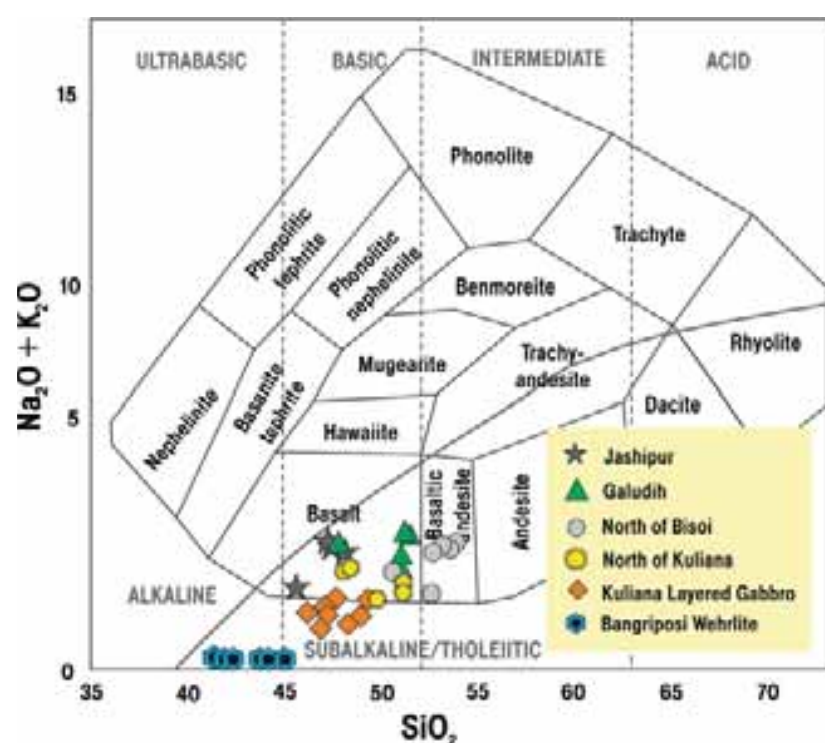

Figure 7. TAS diagram (Cox et al. 1979) showing plots of mafic-ultramafic rocks from Jashipur, North of Bisoi, Galudih, North of Kuliana, KLG and BW. All of the samples classify as 'subalkaline' rocks and all of the rocks, except KLG and BW, plot in either 'basalt' or 'basaltic andesite' field.

of the analysed clinopyroxenes yielded consistent pressure estimates using the CpxBar program.

\section{Geochemistry}

These gabbroic rocks from Galudih have $\mathrm{SiO}_{2}$ contents $>47 \mathrm{wt} \%$ and a plot in the basalt field of the total alkali silica (TAS) plot (Cox et al. 1979) (figure 7). They have moderate $\mathrm{Mg} \#$ numbers (36-51), and $\mathrm{Al}_{2} \mathrm{O}_{3}$ values in the range of $13-15$ wt\%. The iron content of these rocks is moderate (11-14 wt\%) with low $\mathrm{TiO}_{2}$ (0.8-1.1 wt\%). Immobile element concentrations are relatively low: $\mathrm{Cr}$ (70-267 ppm), Ni (88-113 ppm), Zr (46-85 ppm) and $\mathrm{Nb}(3-7 \mathrm{ppm})$. Mobile elements, on the other hand, have relatively higher concentrations: $\mathrm{Ba}$ (75-222 ppm), Rb (10-25 ppm) and $\mathrm{Rb} / \mathrm{Sr}$ in the range of $0.05-0.13$. Primitive mantle (PM)-normalised (McDonough and Sun 1995) trace element patterns (figure 8a) display a marked enrichment in mobile elements. A prominent trough at $\mathrm{Nb}$ is present suggesting crustal contamination. Chondrite normalised (Boynton 1984) REE plots also show clear LREE enrichment with $(\mathrm{La} / \mathrm{Yb})_{N}$ values of 2.5-3.7 (figure 8b). The overall abundance is 10-100 times chondritic values with $\mathrm{REE}_{\text {total }}$ in the range of 39 to $68 \mathrm{ppm}$. They have uniform $\mathrm{Sm} / \mathrm{Nd}$ values of 0.25 and high $\mathrm{Eu} / \mathrm{Eu}^{*}$ $(1.8-2)$. 

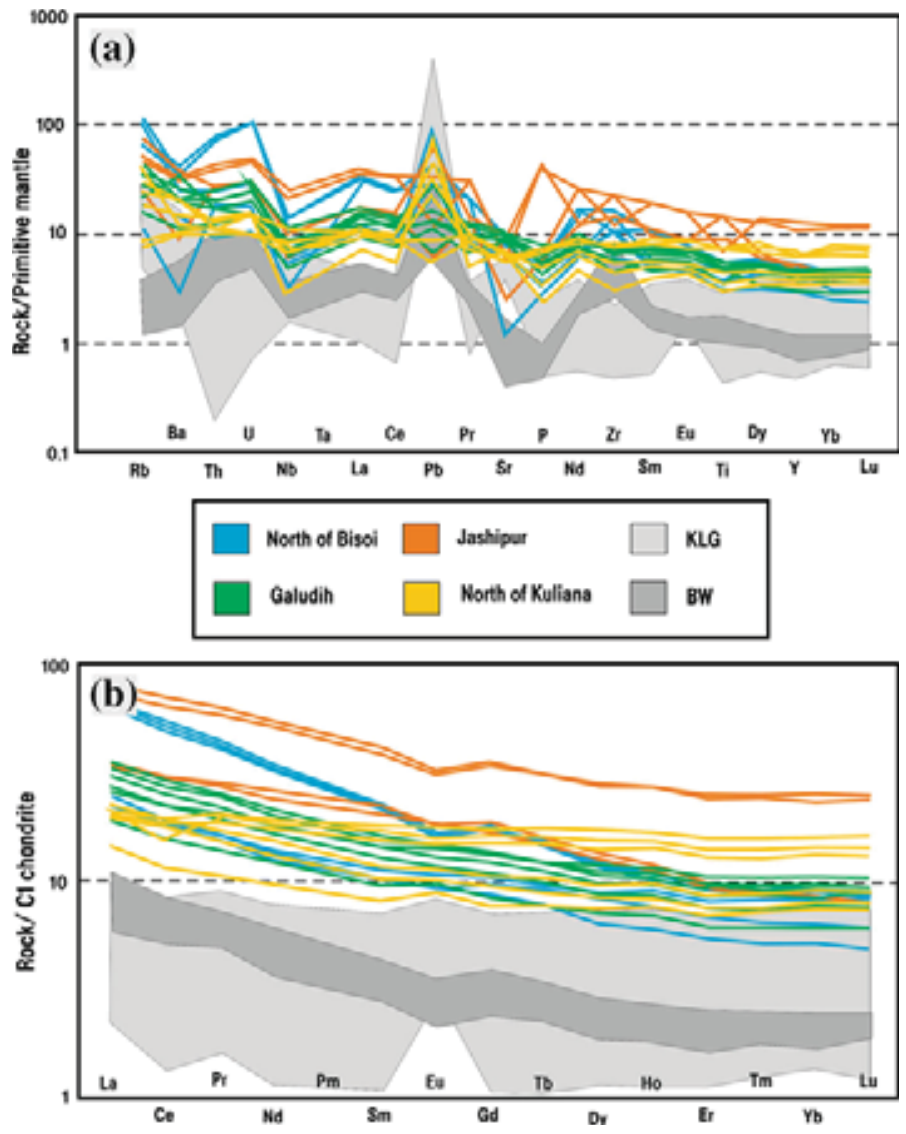

Figure 8. (a) PM-normalised (McDonough and Sun 1995) spider diagram of mafic-ultramafic rocks of Jashipur, North of Bisoi, Galudih, North of Kuliana, KLG and BW. (b) Chondrite normalised (Boynton 1984) REE diagram of mafic-ultramafic rocks of Jashipur, North of Bisoi, Galudih, North of Kuliana, KLG and BW. See text for detailed discussions. The data of KLG and BW are taken from Chakraborti et al. (2016, 2017, 2018).

Most of the dolerite rocks from the North of Bisoi fall in the basaltic andesite field in the TAS plot, having $\mathrm{SiO}_{2}$ values of $43-54 \mathrm{wt} \%$ (figure 7). A high degree of variability is observed in terms of $\mathrm{Al}_{2} \mathrm{O}_{3}$ (6-12 wt\%), $\mathrm{CaO}(6-11$ wt\%) and LOI (0.7-2.4 wt\%). $\mathrm{Mg} \#$ also has a wide range from 55 to 69 . Iron content has a relatively restricted range of 10-14 wt\%. These mafic rocks have high $\mathrm{Cr}$ (400-2500 ppm) and $\mathrm{Ni}(220-520 \mathrm{ppm})$, and relatively lower $\mathrm{Ba}(20-270 \mathrm{ppm}), \mathrm{Rb}(\sim 3$ to $70 \mathrm{ppm})$ with variable $\mathrm{Rb} / \mathrm{Sr}(0.08-0.5)$. A PM normalised (McDonough and Sun 1995) trace element plot (figure 8a) shows highly erratic patterns reflecting the observed elemental variability. The $\mathrm{Nb}$ trough and $\mathrm{Pb}$ peak are present here as well, with added troughs at $\mathrm{Ba}$ and $\mathrm{P}$. Although not conspicuous, a slight overall enrichment in mobile elements is observed. The immobile elements, however, seem depleted and almost reach PM concentrations. Chondrite-normalised (Boynton 1984) REE patterns (figure 8b) also reflect this variability with variable degrees of overall enrichment
( $\left.\mathrm{REE}_{\text {total }} \sim 20-110 \mathrm{ppm}\right)$. A clear LREE enrichment is observed with $(\mathrm{La} / \mathrm{Yb})_{N}$ in the range of 2.7-7.4. However, based on the overall pattern, two groups can be categorised: Group A is almost unfractionated with very low-LREE enrichment and Group B is much more LREE enriched (figure $8 \mathrm{~b}$ ). $\mathrm{Eu} / \mathrm{Eu}^{*}$ varies from 1.5 to 1.8 but some of the more enriched members show a slight Eu-anomaly (figure 8b).

High-LOI content $\sim 8-9.3$ wt\% of the BW rocks reflects the effects of extensive serpentinisation. $\mathrm{SiO}_{2}$ values are $41-44 \mathrm{wt} \%$ and they plot outside the field in the TAS plot (figure 7). The $\mathrm{Mg} \#$ of these rocks is low (72-77), which can be attributed to the elevated total $\mathrm{FeO}$ contents (12-15 wt\%) due to magnetite crystallisation during serpentinisation. LILEs (Ba, Th and U) have enrichment peaks in PM-normalised plots (figure 8a; McDonough and Sun 1995), with accompanying enrichment in $\mathrm{Pb}$ and $\mathrm{Zr}$. Distinct depletion troughs can be seen at $\mathrm{Sr}$ and $\mathrm{Nb}$ and some of the heavier elements ( $\mathrm{Dy}, \mathrm{Y}, \mathrm{Yb}$ and $\mathrm{Lu}$ ) 
show systematic depletion patterns. Significant LREE enrichment is observed (figure 8b) in these rocks (of the order of 10 times chondrite values; Boynton 1984) and $(\mathrm{La} / \mathrm{Yb})_{N}$ ratios range from 3.6 to 4.9 . KLG rocks have $\mathrm{SiO}_{2}$ varying from 46 to 49 wt\%, $\mathrm{Na}_{2} \mathrm{O}+\mathrm{K}_{2} \mathrm{O}$ from 1.2 to $1.9 \mathrm{wt} \%$ and $\mathrm{Mg} \#$ from 56 to 70 . Most of the KLG samples also plot outside the designated fields in the TAS diagram (figure 7). $\mathrm{CaO}$ contents show similar restricted ranges varying from 12.8 to $14.4 \mathrm{wt} \%$ and $\mathrm{Al}_{2} \mathrm{O}_{3}$ varying from 15.4 to $24.24 \mathrm{wt} \%$. $\mathrm{FeO}$ contents are moderate (3.86-7.32 wt\%), and $\mathrm{TiO}_{2}, \mathrm{MnO}$ and $\mathrm{P}_{2} \mathrm{O}_{5}$ show very low values. In spider plots (McDonough and Sun 1995), KLG rocks show depletion troughs at $\mathrm{Th}, \mathrm{Ti}$ with peaks at $\mathrm{Pb}$ and $\mathrm{Sr}$ (figure 8a). REE plots show no appreciable LREE enrichment with prominent positive Eu anomalies (figure 8b). Overall, the trace element character of the KLG rocks can be considered as unfractionated with low enrichment.

Dolerite dykes from North of Kuliana have $\mathrm{SiO}_{2}$ values of $48-51 \mathrm{wt} \%$ and plot in the basalt field in the TAS plot (figure 7). They also have relatively low $\mathrm{Mg} \#$ (35-57) suggesting their chemically differentiated nature. $\mathrm{Al}_{2} \mathrm{O}_{3}$ values are 13-15 wt\% and the iron contents are in the range of 10-16 $\mathrm{wt} \%$. LOI values are relatively less ( $\leq 1 \mathrm{wt} \%)$. Among the immobile elements, $\mathrm{Cr}$ contents are moderate (150-350 ppm), low $\mathrm{Ni}(85-150 \mathrm{ppm})$ and low $\mathrm{Zr}(<90 \mathrm{ppm})$. Ba contents are variable (65-135 ppm) and $\mathrm{Rb} / \mathrm{Sr}$ values are in the range of 0.04-0.2. PM-normalised (McDonough and Sun 1995) trace element plots show no overall discernible pattern, but a slight enrichment in mobile elements can be identified (figure 8a). The trough at $\mathrm{Nb}$ is prominent, and with significant $\mathrm{Pb}$ the peak might reflect effects of crustal assimilations. In chondrite normalised (Boynton 1984) REE plots, two groups can be distinguished (figure $8 \mathrm{~b}$ ): (A) unfractionated group with flat REE patterns, $(\mathrm{La} / \mathrm{Yb})_{N} \leq 1.5, \quad \mathrm{Sm} / \mathrm{Nd} \sim 0.3$ and $\mathrm{REE}_{\text {total- }}$ $<62$ ppm; (B) LREE-enriched group with (La/ $\mathrm{Yb})_{N} \leq 2.7, \mathrm{Sm} / \mathrm{Nd} \sim 0.26$ and relatively lower $\mathrm{REE}_{\text {total }}$ values in the range of 32-48 ppm.

Dolerites from the Jashipur plot in the basalt field of the TAS plot (figure 7), having $\mathrm{SiO}_{2}<48$ wt\%. They have a wide range of $\mathrm{Mg} \#(28-60)$ and low values of $\mathrm{CaO}\left(7-9\right.$ wt\%) and $\mathrm{Al}_{2} \mathrm{O}_{3}(<12$ wt\%). LOI values (1.3-3.5 wt\%) are also a little bit high, reflecting the effects of pervasive hydrothermal alteration observed in these rocks. High abundance of $\mathrm{Fe}-\mathrm{Ti}$ oxides in these rocks has resulted in relatively higher values of iron (13-19 wt\%) and $\mathrm{TiO}_{2}(1.4-2.9$ wt\%). $\mathrm{Cr}$ and $\mathrm{Ni}$ are also high with ranges of 75-710 ppm and 96-847 ppm, respectively. High-Zr (128-236 ppm) values might indicate the presence of metamorphic zircons in these rocks. Ba contents are high (59-254 ppm) and $\mathrm{Rb} / \mathrm{Sr}$ is in the range of $0.2-0.3$. PM-normalised (McDonough and Sun 1995) spider patterns are highly enriched (figure 8a) with troughs at $\mathrm{Nb}, \mathrm{Sr}$ and $\mathrm{Ba}$. These plots overall show no discernible pattern which is indicative of the deformed nature of these rocks. Similar degrees of enrichment $\left(\mathrm{REE}_{\text {total }} \sim 70-170 \mathrm{ppm}\right)$ are observed in the chondrite-normalised (Boynton 1984) REE patterns (figure $8 \mathrm{~b}$ ). A slight LREE enrichment is also discernible with $(\mathrm{La} / \mathrm{Yb})_{N} \sim 3-4$. These rocks can also be grouped in the same manner as mafic rocks $\mathrm{N}$ of Kuliana and Bisoi based on LREE enrichment, Group A has relatively less LREE enrichment and relatively prominent negative Eu anomaly, whereas Group B has much higher LREE enrichment and stronger negative Eu anomalies.

\section{Discussion}

\section{1 'Early proterozoic gabbro-anorthosite suite' group - a critical assessment}

\subsubsection{Field features}

The mafic-ultramafic rocks of this study have different field characteristics. Apart from the KLG and BW rocks, all four are found as intrusive within the MBG rocks. Evidence of intrusive activity ranges from granitic xenoliths in gabbroic rocks of Galudih, to apophytic tongues and crosscutting relationship of dolerite from North of Bisoi along certain zones within granitic country rocks, to linear dyke-like appearance in the case of North of Kuliana dolerite dykes. Three important conclusions can be drawn from evidence: (i) These mafic rocks were emplaced as melts within the granitic country rocks, (ii) they exclusively intruded the Mesoarchaean granitic rocks (MBG and BGG) and (iii) they must be younger than the 3.09 Ga MBG and 3.08-3.12 Ga BGG units. This last inference is vital as it rules out the possibility of grouping the mafic-ultramafic rocks of Sukinda-Nuasahi complex together. The Sukinda-Nuasahi rocks are considered to be of $3.1 \mathrm{Ga}$ (Auge et al. 2003) and thus have to be treated as a separate entity. In stark contrast to the four mafic intrusive rock units, the KLG and BW are found 
within the metapelites of NSMB. Although the contact between the KLG-BW and the metapelites could not be observed in the field, they have no evidences of intrusive activity such as xenoliths, chilled margins or feeder dykes, and are considered to have been emplaced in the solid state by thrust activity (Chakraborti 2018). These rocks are parallel to the regional foliation of the NSMB rocks. It is therefore clear that the four mafic rock units of Galudih, North of Bisoi, North of Kuliana and Jashipur have very different field features compared to the KLG and BW units, which ultimately indicates different modes of emplacement for them.

\subsubsection{Structure and petrographical considerations}

Among the six mafic-ultramafic rock units described in this study, conspicuous evidence of deformation has only been found in the Galudih rocks. These rocks display effects of at least one generation of deformation in the field in the form of foliation, and two generations of deformation under the microscope, in the form of folded foliations. This feature can be considered as a diagnostic evidence of an older age of these rocks compared to the other members of the group. The mafic-ultramafic rocks of Jashipur, North of Bisoi, North of Kuliana, along with KLG exhibit no signs of deformation and should therefore be relatively younger than the mafic rocks of Galudih. BW rocks do show slightly foliated nature in the field, especially in the more serpentinised zone. But, under the microscope they show no evidence of development of any planar fabric.

Another important distinction among the rock groups arises from petrographical characteristics. All the four mafic dyke units exhibit features of hydrothermal alteration in varying degrees, such as the saussuritisation of plagioclase resulting in clouded grains, amphibolitisation of clinopyroxene and development of quartz-alkali feldspar intergrowth. KLG rocks on the other hand appear fresh under the microscope and are completely devoid of these alteration features. This indicates that in the late/post-crystallisation stage, a fluid phase reacted with the mafic dyke rocks, rendering them with greenschist facies characteristics and evidently, this event did not play a role in the crystallisation history of KLG. BW rocks on the other hand have a complex and multi-stage metasomatic history (Chakraborti et al. 2018).

\subsubsection{Mineralogical and chemical composition}

Subtle chemical differences are present among the six mafic-ultramafic rock units. However, it is important to mention that some of the variations are expected as the mafic dykes represent hypabyssal intrusive rocks, whereas the KLG and BW represent plutonic cumulate and mantle rocks. Plagioclase compositions have much higher anorthite contents in KLG rocks, than the other mafic rock groups (figure 6a). Clinopyroxenes are primarily augitic within the mafic dyke rocks, with minor ferro-augite and pigeonite (figure $6 \mathrm{~b}$ ). KLG and $\mathrm{BW}$ rocks have diopsidic variety along with augite, which also has a slightly different compositional range with sub-calcic varieties (figure $6 \mathrm{~b}$ ). $\mathrm{Al} / \mathrm{Ti}$ of clinopyroxene is an important parameter which is controlled by the cooling rate and silica activity (Nisbet and Pearce 1977; Beccaluva et al. 1989). Clinopyroxenes from KLG and BW (primary) display overlap in terms of the $\mathrm{Al} / \mathrm{Ti}$ values with the other mafic rock units (figure 9). However, the higher $\mathrm{Mg} \#$ range of the KLG and BW discriminate them from the rest (figure 9). Also, Ti values of clinopyroxene are directly correlated with whole rock $\mathrm{TiO}_{2}$ values, thus reflecting the low-Ti nature of the KLG compared to others. Overall, KLG and BW have more primitive clinopyroxene with slightly lower $\mathrm{Al} / \mathrm{Ti}$ and high $\mathrm{Ca}$-plagioclase than the other mafic rock units.

Discrimination in terms of whole rock major and trace element concentrations is much more

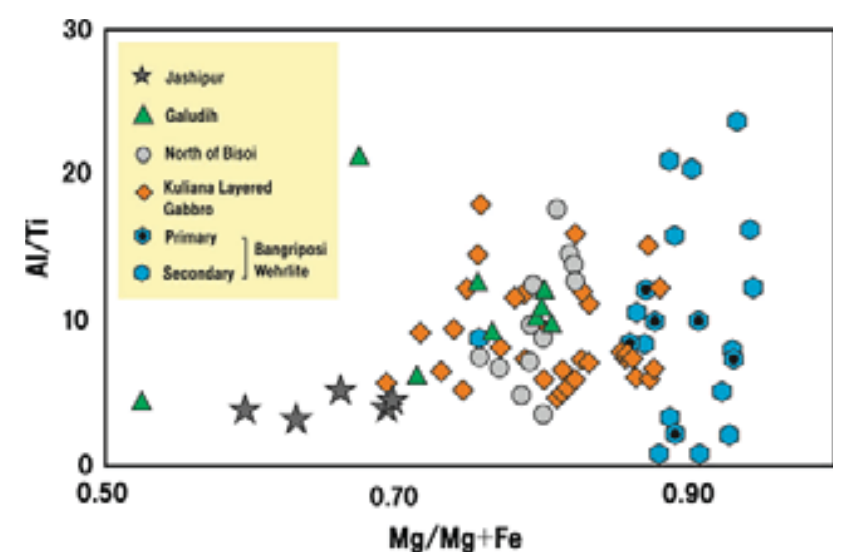

Figure 9. Compositional variation among clinopyroxenes from the mafic-ultramafic rocks of Jashipur, North of Bisoi, Galudih, KLG and BW. All of the rocks have more or less overlapping values of $\mathrm{Al} / \mathrm{Ti}$ ratios. However, the relatively higher $\mathrm{Mg}$ \# of KLG and BW helps to discriminate them from the rest. The data of KLG and BW are taken from Chakraborti et al. (2016, 2017, 2018). 

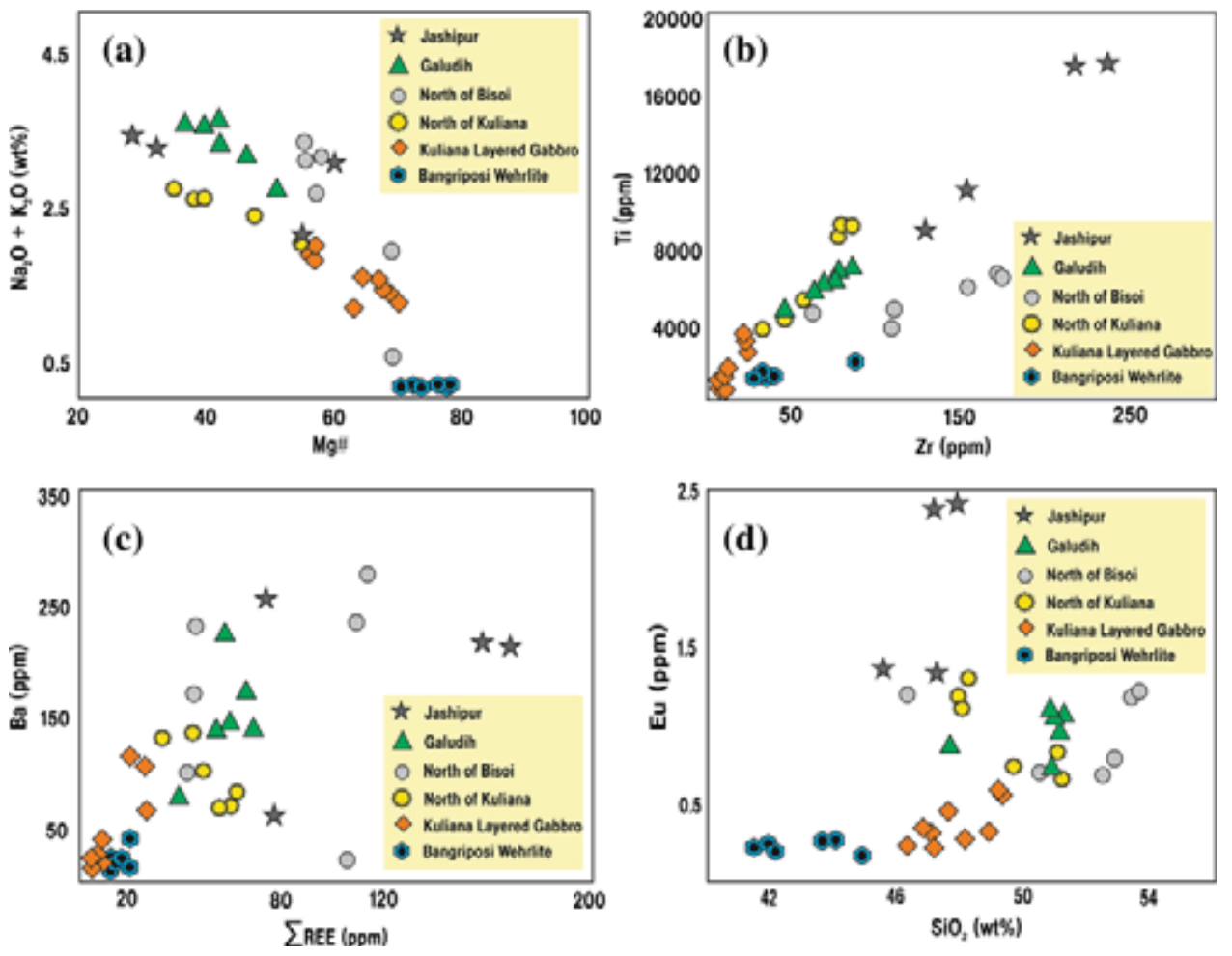

Figure 10. Whole-rock major and trace element plots displaying the geochemical variation among all the studied maficultramafic rock units. (a) $\mathrm{Na}_{2} \mathrm{O}+\mathrm{K}_{2} \mathrm{O}$ vs. $\mathrm{Mg} \#$ diagram shows that the $\mathrm{KLG}$ and $\mathrm{BW}$ rocks have relatively lower $\mathrm{Na}_{2} \mathrm{O}+\mathrm{K}_{2} \mathrm{O}$ and higher Mg\# values than the rest; (b) Ti vs. Zr diagram shows overlapping plots, with KLG and BW having the lowest values; (c) Ba vs. $\mathrm{REE}\left(\mathrm{REE}_{\text {Total }}\right)$ diagram shows that the KLG and BW rocks have low-REE $\mathrm{Total}_{\text {and }}$ Ba contents, which discriminate from the rest. (d) $\mathrm{Eu}$ vs. $\mathrm{SiO}_{2}$ diagram shows overlap in the $x$-axis. However, the low-Eu contents of KLG and BW distinguish them from the rest. The data of KLG and BW were taken from Chakraborti et al. (2016, 2017, 2018) (see text for details).

ambiguous. The mafic-ultramafic rocks exhibit many similarities, along with subtle differences. In general, the KLG and BW rocks have lower alkali $\left(\mathrm{Na}_{2} \mathrm{O}+\mathrm{K}_{2} \mathrm{O}\right)$ content with higher $\mathrm{Mg} \#$ values compared to mafic dykes (figure 10a). All the rock units except the mafic rocks of Jashipur (highly scattered) have similar $\mathrm{Ti}$ and $\mathrm{Zr}$ concentrations, with KLG and BW representing the lowest values (figure 10b). The higher $\mathrm{Zr}$ concentrations of the mafic dyke rocks possibly indicate the assimilation of the crustal material, and the low-Ti content of the KLG and BW rocks has been inferred to be a feature of the mantle source. Depletion troughs of $\mathrm{Nb}$, also an evidence of crustal assimilation is absent in the PM-normalised spider plots of KLG (figure 8a). BW rocks exhibit negative $\mathrm{Nb}$ anomaly, but that can be attributed to their complex metasomatic history involving the interaction with an alkali-carbonatite melt at mantle depths and a shallow level serpentinisation event (for more details see Chakraborti et al. 2018). In these two diagrams (figure 10a and b), the plotted maficultramafic rocks display an apparent colinearity.
KLG and BW rocks also have relatively lower $\mathrm{REE}_{\text {total }}$ and $\mathrm{Ba}$ concentrations than the rest, but there is a minor overlap (figure 10c). Also, their lower Ba concentrations suggest that the addition of LILE elements did not play a significant part in their petrogenesis (figure 10c). Although all the rock units have overlapping $\mathrm{SiO}_{2}$ contents, relatively low-Eu concentrations of the KLG and BW help discriminate them from the rest (figure 10d). Apart from the KLG and BW rocks, the four mafic rock units exhibit overlapping fields in the bivariate diagrams in figure 10. These overlaps in whole rock major and trace element concentrations among the six mafic-ultramafic rock units highlight the fact that they belong to the same terrain and thus have experienced similar tectonic episodes. Also, each of them have variable contributions from the sub-continental lithospheric mantle of the SC. The apparent colinearity displayed in some of the bivariate diagrams possibly result from these causes as well. Thus, it goes to show that discrimination based solely on whole rock geochemistry should be avoided. Nonetheless, it is 
worth mentioning that a few subtle differences exist between the KLG-BW and the other four rock units.

It was found through multi-stage trace element modelling that the BW rocks serve as the source for KLG rocks (Chakraborti 2018). For this modelling process, the calculated equilibrium melts of KLG (Chakraborti et al. 2016) were utilised. The multistage modelling consisted of calculating selected trace element concentrations of partial melts from BW. Then in the next step, these calculated melts were subjected to fractional crystallisation, and the final melts were calculated with the equilibrium melts of KLG. The results showed a clear match and hence, it was concluded that the BW suffered partial melting to produce mafic melts that underwent substantial amounts of fractionation before crystallising the observed sequence of KLG. However, it is noteworthy that KLG and BW being mid-crustal cumulate and mantle rocks, respectively, show overlapping fields in the $\mathrm{Ti} v s$. $\mathrm{Zr}$ and $\mathrm{Ba} v s$. $\mathrm{REE}_{\text {total }}$ space. Two possible reasons offer explanations: (i) pervasive serpentinisation of the BW rocks altered their geochemistry and must have affected lighter elements such as Ba; (ii) KLG rocks are cumulate rocks, which means they do not directly reflect the chemical character of their parent melts (Bédard 1994; Chakraborti et al. 2016).

As the KLG and BW rocks represent an oceanic magma chamber sequence and the underlying mantle, an important point of consideration is whether the dolerite dykes of Jashipur, North of Bisoi and North of Kuliana belong to that genetic group, representing sheeted dykes of a classical oceanic-magma chamber sequence. Field evidence argues against such a genetic connection. Nonetheless, REE modelling has been performed to examine the possibility of such a connection. The assumption is that, if the mafic dykes are cogenetic with KLG and BW, then they represent melts formed by fractionation from the residual melts after KLG crystallisation. The REE concentrations of the residual melts were calculated in an earlier study (Chakraborti et al. 2018) and used here. The modelled melts with $10-50 \%$ fractionation were compared with the mafic dyke rocks (figure 11). The modelled melts have a much higher total REE ( 100-400 ppm), and stronger $\mathrm{Eu}$ anomaly $\left(\mathrm{Eu} / \mathrm{Eu}^{*} \sim 0.3-0.6\right)$ compared to the mafic dykes (total REE 40-160 ppm; Eu/ $\mathrm{Eu}^{*} \sim$ 0.8-1.1). Although conspicuous distinction by whole rock geochemical data has been avoided,

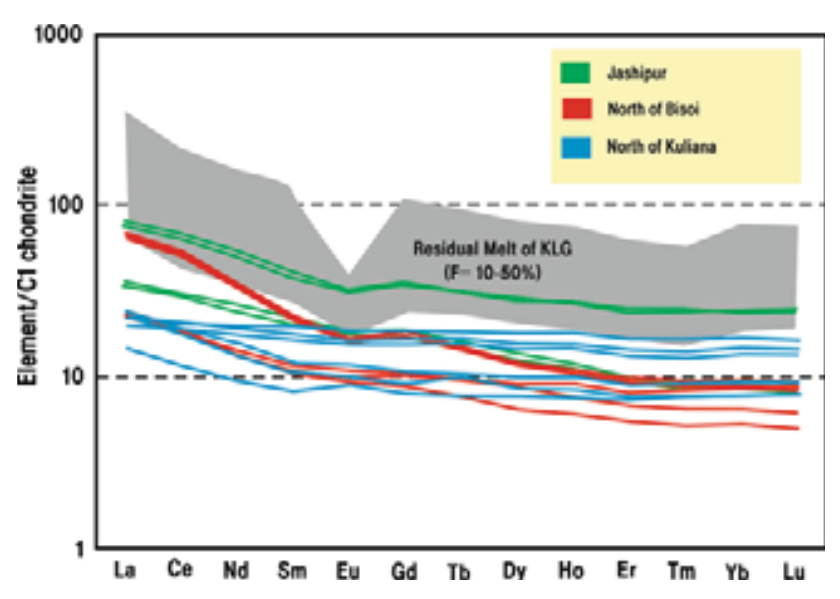

Figure 11. Chondrite normalised (Boynton 1984) REE diagram for comparison of dolerite dyke rocks of Jashipur, North of Bisoi and North of Kuliana, with modelled residual melts after the crystallisation of the KLG sequence. The residual melts were modelled at 10 to $50 \%$ fractionation $(F=10-50 \%)$. The modelled melts have higher total REE, and stronger negative Eu anomalies than the mafic dyke rocks.

the results of this modelling provide another evidence against the mafic-ultramafic rocks being co-genetic.

\subsubsection{Reappraisal of the grouping}

The previous discussions suggest that although the distinction among the six mafic-ultramafic rock units are subtle and inconspicuous in terms of whole-rock geochemistry, many undeniable discriminating evidence exist in their field features, petrography, structural histories and mineralogy. Based on these evidences, the grouping of these mafic-ultramafic rock units together as the 'early proterozoic gabbro-anorthosite suite' is found to be incorrect. It is proposed that instead of a single cogenetic group, these rocks should be categorised into three separate groups:

(a) Group I: The gabbroic rocks of Galudih represent the oldest units among the rocks, as evidenced by their multiply deformed nature. These rocks have suffered at least two generations of deformations and this feature alone distinguishes these gabbroic rocks from the rest. These mafic rocks of Galudih could possibly belong to one of the older volcanosedimentary complexes of the SC, but without geochronological data it is difficult to identify the stratigraphic position of these mafic rocks. They share similarities in whole-rock geochemistry with the mafic rocks of Jashipur, North of Bisoi and North of Kuliana. Also, their 

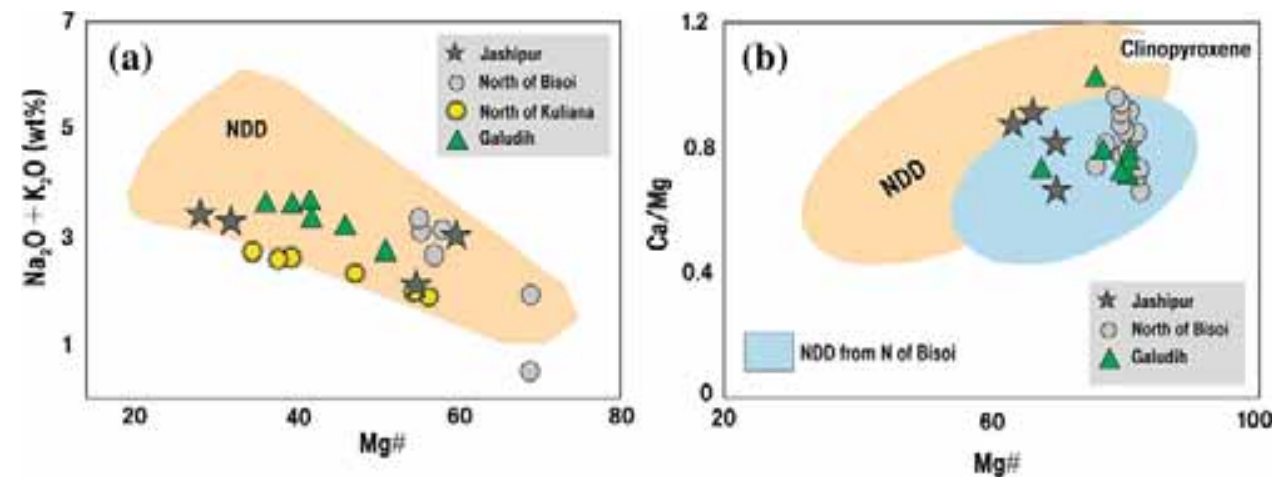

Figure 12. Bivariate diagrams for comparison of dolerite dykes of Group II (Jashipur, North of Bisoi and North of Kuliana) with the NDD rocks (shaded polygon). Gabbroic rocks of Galudih, belonging to Group I, have also been spotted for comparison (whole-rock data of NDD rocks taken from Mir et al. (2010) and Sengupta and Ray (2012); clinopyroxene data of NDD taken from Sengupta et al. (2014)). (a) In the whole-rock $\mathrm{Na}_{2} \mathrm{O}+\mathrm{K}_{2} \mathrm{O}$ vs. $\mathrm{Mg} \#$ diagram, the Group II rocks plot in the field of NDD rocks; (b) in the clinopyroxene $\mathrm{Ca} / \mathrm{Mg}$ vs. $\mathrm{Mg} / \mathrm{Mg}+\mathrm{Fe}^{+2}$ diagram, the Group II and NDD rocks exhibit overlapping fields. The data of NDD rocks are from the North of Bisoi (light yellow ellipse) taken from Maity et al. (2008).

whole rock and clinopyroxene chemistry are comparable to NDDs of SC (figure 12).

(b) Group II: Dolerites from Jashipur, North of Bisoi and North of Kuliana belong to a single group. All of these rock units are completely undeformed, display various evidences of intrusive activity in the field, have similar petrography, mineralogy and geochemistry. They can be classified as mafic dyke intrusions within the continental crust. The NDD swarm (Saha 1994) represents the major

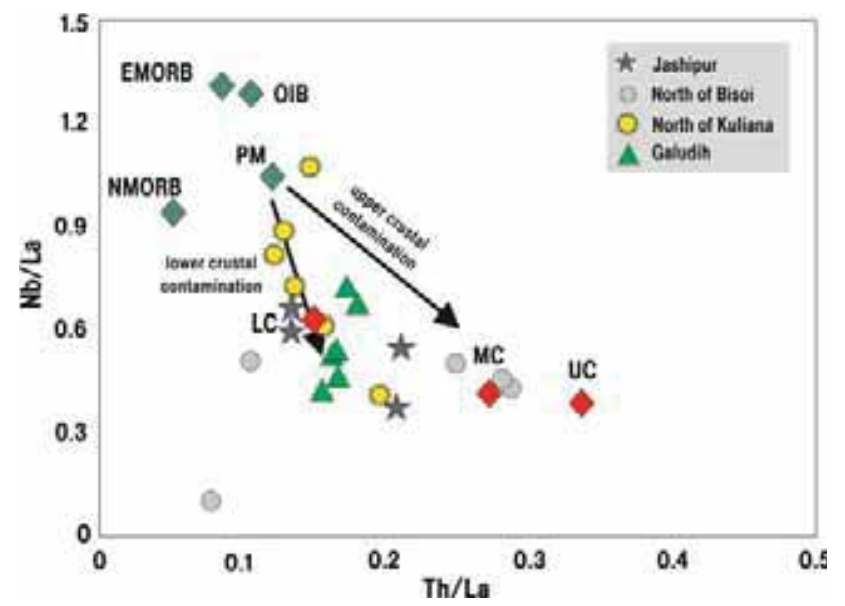

Figure 13. $\mathrm{Nb} / \mathrm{La}$ vs. Th/La diagram to assess the input of crustal contamination in the petrogenesis of Group I and Group II mafic rocks. The majority of the data points plot between PM and lower crustal compositions, suggesting the lower crust is the primary contaminant. Evidence of minor amounts of middle crustal contamination is also visible (PM, NMORB, EMORB and ocean island basalt (OIB) values taken from Sun and McDonough 1989; upper crust (UC), middle crust (MC) and lower crust (LC) values taken from Rudnick and Gao 2003). mafic dyke unit of the SC. The mafic rocks of Jashipur, North of Bisoi and North of Kuliana share identical hydrothermal alteration features with the NDD rocks (Sengupta and Ray 2012). To check the geochemical affinity of the mafic rocks, whole-rock and clinopyroxene data have been compared with NDD rocks (figure 12). In the $\mathrm{Na}_{2} \mathrm{O}+\mathrm{K}_{2} \mathrm{O}$ vs. $\mathrm{Mg} \#$ (figure 12a) plot, the mafic rocks of Group II show remarkable similarities with NDD rocks. The comparison of clinopyroxene compositions also yields the same result (figure 12b). These rocks have REE patterns that can be subdivided into two groups based on variable LREE enrichment (figure 8b), which is similar to the REE characteristics of the NDD rocks (Sengupta and Ray 2012). It is also worth mentioning here that Maity et al. (2008) while carrying out a mineralogical study on the mafic dykes from North of Bisoi, considered them to be a part of NDD rocks. Hence, all the evidences suggest that the mafic intrusive rocks of Jahsipur, North of Bisoi and North of Kuliana possibly belong to the NDD swarm of the SC. Misra (2006) divided the emplacement of NDD rocks into three separate pulses: $2.0 \mathrm{Ga}, 1.6 \mathrm{Ga}$ and 1.2-1.0 Ga. However, this division is based on older ages and hence, has not been wholly accepted. More recently, $\mathrm{Pb}-\mathrm{Pb}$ baddeleyite dating of these rocks have provided precise ages of $\sim 1.76 \mathrm{Ga}$ (Shankar et al. 2014) and $\sim 2.8 \mathrm{Ga}$ (Kumar et al. 2017). The exact emplacement ages of the NDD still remain a debated issue at this point. 
(c) Group III: The KLG and BW belong to a single co-genetic group. Both of them show no evidence of intrusive activity and are found in proximity to the BSZ. These rocks represent obducted fragments of oceanic crust and metasomatised mantle within metapelites of a mobile belt (Chakraborti 2018). Although Prabhakar et al. (2014) have associated these rocks with the $1.0 \mathrm{Ga}$ amalgamation of the Northern and Southern Indian Block, no direct age data have been obtained so far.

\subsection{Petrogenetic implications}

The tectonic and petrogenetic implications of the KLG and BW of Group III have already been explored in our previous studies. They originally formed in an oceanic setting and later got accreted onto an orogenic belt assemblage (Chakraborti 2018). However, as mentioned earlier, no geochronological data are available on these rocks, which hinders the recognition of the orogenic event that is responsible for their obduction. As a consequence, their stratigraphic position within the $\mathrm{SC}$ is still unclear at this point.

The similarity in terms of whole-rock geochemistry between Group I and Group II rocks are noteworthy. Even though Group I rocks are definitely older than Group II and hence not co-genetic, both can be categorised as intrusions of mafic melts into the continental crust. In $\mathrm{Nb} / \mathrm{La}$ vs. Th/ La diagram (figure 13), the Group I and Group II rocks exhibit evidence of suffering significant amounts of crustal contamination. This is also in agreement with the elevated $\mathrm{Zr}$ contents of these rocks. The contribution of the lower crust is possibly greater (figure 13). In the clinopyroxene discrimination diagrams of Beccaluva et al. 1989 (figure 14), the composition of clinopyroxene grains from Group I and II exhibit significant overlap. In the $\mathrm{SiO}_{2} / 100-\mathrm{TiO}_{2}-\mathrm{Na}_{2} \mathrm{O}$ diagram, clinopyroxenes from Jashipur and Galudih exhibit large scatter and plot in overlapping fields designated for clinopyroxenes from island arc tholeiites (IAT), boninites (Bon), normal MORBs (NM) and back-arc basin basalts (BABB) (figure 14a). Clinopyroxenes from North of Bisoi fall outside the fields and show minor affinities towards IAT clinopyroxenes (figure 14a). The scatter is much less in the Si vs. Al diagram, where clinopyroxenes from both Group I and Group II plot close to each other and display affinities for clinopyroxenes from
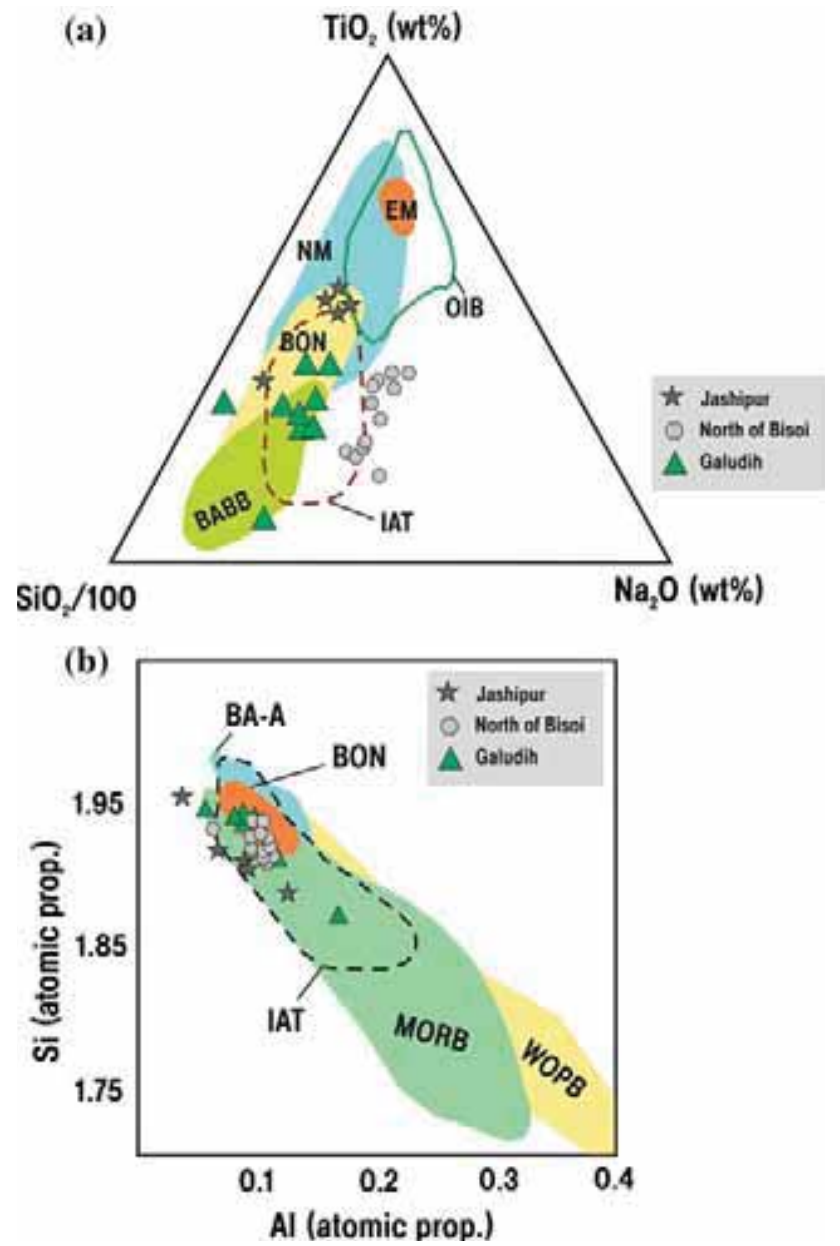

Figure 14. Tectonic discrimination diagrams of clinopyroxene (after Beccaluva et al. 1989). Both Group I and Group II clinopyroxenes plot in overlapping fields and show affinities towards Bon, IATs, MORBs and BABBs (EM: enriched midocean ridge basalt, NM: normal mid-ocean ridge basalt, OIB: ocean island basalt, Bon: boninite, IAT: island arc tholeiite, BABB: back-arc basin basalt, BA-A: back-arc andesite, WOPB: within plate oceanic basalt, MORB: mid-ocean ridge basalt).

MORBs, IATs and BONs (figure 14b). In general, the low- $\mathrm{Ti}$ and $\mathrm{Al}$ proportions of clinopyroxenes from Group I and II correspond more closely to clinopyroxenes from boninitic melts. Although tectonic discrimination is not straightforward from these diagrams, it can be stated that the mineralogical and geochemical resemblance shared by Group I and II rocks could possibly indicate similar petrogenetic histories.

As discussed earlier, Group II rocks possibly belong to the NDD swarm of the SC. Melting of a metasomatised mantle wedge and E-MORB type mantle in a subduction-zone setting has been hypothesised for the NDD rocks (Sengupta and Ray 2012), and a similar petrogenesis might also be assumed for the Group II dykes. However, there is 
chronological debate surrounding the NDD rocks and ages from the Neoproterozoic to Neoarchaean have been suggested (Bose 2009; Shankar et al. 2014; Kumar et al. 2017). The Group I rocks on the other hand with evidence of deformation in at least two-generations, possibly belong to one of the older supracrustal assemblages of the SC. However, without further petrological investigations or geochronological data, it is difficult to identify their petrogenetic history at this point of time.

It is hoped that future studies on these rocks, involving precise isotopic and geochronological work will provide insights into the petrogenetic history of these rocks groups and firmly establish their stratigraphic position in the SC.

\section{Summary and conclusions}

(a) The work focuses on mafic-ultramafic rock units from the eastern part of the SC, considered to belong to a single genetic group, dubbed as the 'early proterozoic gabbroanorthosite suite'.

(b) The mafic-ultramafic rock units studied in this work are: (i) gabbro of Galudih, (ii) dolerite from North of Bisoi, (iii) BW, (iv) dolerite from North of Kuliana, (v) KLG and (vi) dolerite of Jashipur.

(c) Considerable variations exist among the members of this group, in terms of field features, petrography, mineralogy and geochemistry.

(d) After critical assessment of the grouping of these rocks, it was found that categorising them as one co-genetic group is erroneous. Instead, it is proposed that they should be re-categorised into three separate groups:

Group I: Gabbroic rocks of Galudih.

Group II: Dolerite dykes from Jashipur, North of Bisoi and North of Kuliana.

Group III: Dismembered gabbro-wehrlite rocks of Bangriposi-Kuliana (BW and KLG).

(e) Group II mafic dykes possibly belong to the NDD array, and Group III rocks represent obducted fragments of oceanic crust and an underlying mantle onto a mobile belt assemblage. The palaeotectonic affinity of the Group I is still unclear at this point.

(f) Geochemistry and mineralogy of Group I and Group II rocks suggest the involvement of crustal contamination and formation in a subduction-zone setting.

\section{Acknowledgements}

The authors wish to thank the Head of the Department, Department of Geology, Presidency University, Kolkata, for providing infrastructural support. This work was financially supported by the Department of Science \& Technology (DST), India (grant no. SR/S4/ES-646/2012). The authors would also like to extend their gratitude to anonymous reviewers, whose suggestions significantly enhanced the quality of this manuscript. The editorial expertise of Rajneesh Bhutani is also greatly appreciated.

\section{References}

Acharyya S K K, Gupta A and Orihashi Y 2010 NeoarcheanPaleoproterozoic stratigraphy of the Dhanjori basin, Singhbhum craton, eastern India: And recording of a few $\mathrm{U}-\mathrm{Pb}$ zircon dates from its basal part; J. Asian Earth Sci. 39 527-536, https://doi.org/10.1016/j.jseaes.2010.04.023.

Auge T, Cocherie A, Genna A, Armstrong R, Guerrot C, Mukherjee M M and Patra R N 2003 Age of the Baula PGE mineralization (Orissa, India) and its implications concerning the Singhbhum Archaean nucleus; Precamb. Res. 121 85-101, https://doi.org/10.1016/S0301-9268(02)00202-4.

Bandyopadhyay P K, Chakrabarti A K, DeoMurari M P and Misra S 20012.8 Ga old anorogenic granite-acid volcanics association from western margin of the Singhbhum-Orissa craton, eastern India; Gondwana Res. 4 465-475, https:// doi.org/10.1016/S1342-937X(05)70346-4.

Banerjee P K 1997 Geodynamic implications of chrome-poor enstatite bodies in the Sukinda-Baula-Nuasahi ultramafic suites of Orissa; Proc. Indian Acad. Sci. (Earth Planet. Sci.) 106 357-360.

Banerjee P K and Ghosh S 1994 Is the simplipal complex a product of shallow plume tectonics? J. Geol. Soc. India 43 353-359.

Beccaluva L, Macciotta G, Piccardo G B, Zeda O and Loucks R R 1989 Clinopyroxene composition of ophiolite basalts as petrogenetic indicator; Chem. Geol. 77 165-182, https:// doi.org/10.1130/0091-7613(1990)018<346:DOOFNU>2.3. $\mathrm{CO} ; 2$.

Bédard J H 1994 A procedure for calculating the equilibrium distribution of trace elements among the minerals of cumulate rocks, and the concentration of trace elements in the coexisting liquids; Chem. Geol. 118 143-153, https://doi.org/10.1016/0009-2541(94)90173-2.

Bose M K 2009 Precambrian mafic magmatism in the Singhbhum craton, eastern India; J. Geol. Soc. India $\mathbf{7 3}$ 13-35, https://doi.org/10.1007/s12594-009-0002-3.

Boynton W V 1984 Cosmochemistry of the rare earth elements: Meteorite studies; Dev. Geochem. 2 63-114, https://doi.org/10.1016/B978-0-444-42148-7.50008-3.

Chakraborti T M 2018 Petrology of mafic-ultramafic rocks around Bangriposi and Kuliana, Orissa, eastern India: Implication for paleotectonic setting. PhD Thesis, Presidency University, pp. 1-361. 
Chakraborti T M, Ray A and Deb G K 2016 Computation of parent magma compositions of a layered gabbro suite around Kuliana, Orissa, eastern India: Implications for magmatic evolution and paleotectonic setting; J. Geol. 124 723-741, https://doi.org/10.1086/688607.

Chakraborti T M, Ray A and Deb G K 2017 Crystal size distribution analysis of plagioclase from gabbro-anorthosite suite of Kuliana, Orissa, eastern India: Implications for textural coarsening in a static magma chamber; Geol. J. 52 234-248, https://doi.org/10.1002/gj.2752.

Chakraborti T M, Ray A and Deb G K 2018 Evidence of melt/ rock interaction in the Cr-spinel bearing wehrlite rocks of Bangriposi, India: Implications for nature of the metasomatic agent; Geosci. Front. 9 1213-1227, https://doi.org/ 10.1016/j.gsf.2017.08.001.

Chakraborti T M, Ray A, Deb G K, Upadhyay D and Chakrabarti R 2019 Evidence of crustal reworking in the Mesoarchean: Insights from geochemical, U-Pb zircon and Nd isotopic study of a 3.08-3.12 Ga ferro-potassic granitegneiss from north-eastern margin of Singhbhum craton, India; Lithos 330-331 16-34, https://doi.org/10.1016/J. LITHOS.2019.01.026.

Chakraborty K L and Majumder T 1986 Geological aspects of the banded iron-formation of Bihar and Orissa; J. Geol. Soc. India 28 109-133.

Chatterjee P, De S, Ranaivoson M, Mazumder R and Arima M 2013 A review of the $\sim 1600$ Ma sedimentation, volcanism, and tectono-thermal events in the Singhbhum craton, eastern India; Geosci. Front. 4 277-287, https://doi.org/ 10.1016/j.gsf.2012.11.006.

Cox K G, Bell J D and Pankhurst R J 1979 The interpretation of igneous rocks; Springer, Netherlands, Dordrecht, https://doi.org/10.1007/978-94-017-3373-1.

Dunn J A and Dey A K 1942 Geology and petrology of eastern Singhbhum and surrounding areas; Geol. Surv. India Mem. $69281-456$.

Ghiorso M S and Evans B W 2008 Thermodynamics of rhombohedral oxide solid solutions and a revision of the Fe-Ti twooxide geothermometer and oxygen-barometer; Am. J. Sci. 308 957-1039, https://doi.org/10.2475/09.2008.01.

Ghosh D K, Sarkar S N, Saha A K and Ray S L 1996 New insights on the early archaean crustal evolution in eastern India: Re-evaluation of lead-lead, samarium-neodymium and rubidium-strontium geochronology; Indian Miner. 50 $175-188$.

Goswami J N, Mishra S, Wiedenbeck M, Ray S L and Saha A K 19953.55 ga old zircon from Singhbhum-Orissa iron ore craton, eastern India; Curr. Sci., https://doi.org/10.2307/ 24097290.

Hazarika P, Mishra B and Pruseth K L 2015 Diverse tourmaline compositions from orogenic gold deposits in the Hutti-Maski greenstone belt, India: Implications for sources of ore-forming fluids; Econ. Geol. 110 337-353, https://doi.org/10.2113/econgeo.110.2.337.

Iyengar S V P and Alwar M A 1965 The Dhanjori eugeosyncline and its bearing on the stratigraphy of the Singhbhum, Keonjhar and Mayurbhanj Districts; Min. Met. Inst. India, D N Wadia Commemorative Volume 138-162.

Khanna P P, Saini N K, Mukherjee P K and Purohit K K 2009 An appraisal of ICP-MS technique for determination of REEs: Long term QC assessment of silicate rock analysis; Himal. Geol. 30 95-99.
Kumar A, Parashuramulu V, Shankar R and Besse J 2017 Evidence for a neoarchean LIP in the Singhbhum craton, eastern India: Implications to Vaalbara supercontinent; Precamb. Res. 292 163-174, https://doi.org/10.1016/j. precamres.2017.01.018.

Luhr J F, Carmichael I S E and Varekamp J C 1984 The 1982 eruptions of El Chichón volcano, Chiapas, Mexico: Mineralogy and petrology of the anhydrite bearing pumices; $J$. Volcanol. Geotherm. Res. 23 69-108, https://doi.org/10. 1016/0377-0273(84)90057-X.

Maity B K, Ray J, Chattopadhyay B, Sengupta S, Nandy S and Saha A 2008 Contrasting petrological variants in newer dolerite dyke swarm around Bisoi, eastern Indian shield: Insights from petrography and mineral chemistry; In: Indian Dykes: Geochemistry, geophysics and geochronology (eds) Srivastava R K, Sivaji C, Chalapathi Rao N V, Narosa Publishing House Pvt. Ltd., New Delhi, pp. 447-470.

Manikyamba C, Ray J, Ganguly S, Singh M R, Santosh M, Saha A and Satyanarayanan M 2015 Boninitic metavolcanic rocks and island arc tholeiites from the older metamorphic group (OMG) of Singhbhum craton, eastern India: Geochemical evidence for archean subduction processes; Precamb. Res. 271 138-159, https://doi.org/10. 1016/J.PRECAMRES.2015.09.028.

Mazumder R, De S, Ohta T, Flannery D, Mallik L, Chaudhury T, Chatterjee P, Ranaivoson M A and Arima M 2015 PalaeoMesoproterozoic sedimentation and tectonics of the Singhbhum craton, eastern India, and implications for global and craton-specific geological events; Geol. Soc. London Memoir. 43 139-149, https://doi.org/10.1144/M43.10.

McDonough W F and Sun S-S 1995 The composition of the Earth; Chem. Geol. 120 223-253, https://doi.org/10.1016/ 0009-2541(94)00140-4.

Mir A R, Alvi S H and Balaram V 2010 Geochemistry of mafic dikes in the Singhbhum Orissa craton: Implications for subduction-related metasomatism of the mantle beneath the eastern Indian craton; Int. Geol. Rev. 52 79-94, https://doi.org/10.1080/00206810903211948.

Misra S 1999 The Mayurbhanj granite: Its nature, tectonic setting, mode of emplacement and pressure-temperature of magma generation; Indian J. Geol. 71 33-52.

Misra S 2006 Precambrian chronostratigraphic growth of Singhbhum-Orissa craton, eastern Indian shield: An alternative model; J. Geol. Soc. India 67 356-378.

Misra S and Johnson P T 2005 Geochronological constraints on evolution of Singhbhum mobile belt and associated basic volcanics of eastern Indian shield; Gondwana Res. 8 129-142.

Misra S, Deomurari M P, Wiedenbeck M, Goswami J N, Ray $\mathrm{S}$ and Saha A K $1999{ }^{207} \mathrm{~Pb} /{ }^{206} \mathrm{~Pb}$ zircon ages and the evolution of the Singhbhum craton, eastern India: An ion microprobe study; Precamb. Res. 93 139-151, https://doi. org/10.1016/S0301-9268(98)00085-0.

Misra S, Sarkar S S and Ghosh S 2002 Evolution of Mayurbhanj granite pluton, eastern Singhbhum, India: A case study of petrogenesis of an A-type granite in bimodal association; J. Asian Earth Sci. 20 965-989, https://doi. org/10.1016/S1367-9120(02)00002-0.

Mondal S K, Ripley E M, Li C and Frei R 2006 The genesis of archaean chromitites from the Nuasahi and Sukinda massifs in the Singhbhum craton, India; Precamb. Res. 148 45-66, https://doi.org/10.1016/j.precamres.2006.04.001. 
Mondal S K, Frei R and Ripley E M 2007 Os isotope systematics of mesoarchean chromitite-PGE deposits in the Singhbhum craton (India): Implications for the evolution of lithospheric mantle Sisir; Chem. Geol. 244 391-408, https://doi.org/10.1016/j.chemgeo.2007.06.025.

Mukhopadhyay J, Beukes N J, Armstrong R A, Zimmermann U, Ghosh G and Medda R A 2008 Dating the oldest greenstone in India: A 3.51-Ga precise U-Pb SHRIMP zircon age for dacitic lava of the southern iron ore group, Singhbhum craton; $J$. Geol. 116 449-461, https://doi.org/10.1086/590133.

Naha K 1965 Metamorphism in relation to stratigraphy, structure and movement in Singhbhum, East India; Quart. J. Geol. Mineral. Metall. Soc. India 37 41-85.

Nimis P and Ulmer P 1998 Clinopyroxene geobarometry of magmatic rocks part 1: An expanded structural geobarometer for anhydrous and hydrous, basic and ultrabasic systems; Contrib. Mineral. Petrol. 133 122-135, https:// doi.org/10.1007/s004100050442.

Nisbet E G and Pearce J A 1977 Clinopyroxene composition in mafic lavas from different tectonic settings; Contrib. Mineral. Petrol. 63 149-160, https://doi.org/10.1007/BF00398776.

Page N J, Banerji P and Haffty J 1985 Characterization of the Sukinda and Nuasahi ultramafic complexes, Orissa, India by platinum-group element geochemistry; Precamb. Res. 30 27-41, https://doi.org/10.1016/0301-9268(85)90027-0.

Pandey B K, Gupta J N and Lall Y 1986 Whole rock and $\mathrm{Rb}-\mathrm{Sr}$ isochron ages for the granites from Bihar mica belt of Hazaribagh, Bihar, India; Indian J. Earth Sci. 12 157-162.

Prabhakar N, Bhattacharya A, Sathyanarayanan M and Mukherjee P K 2014 Structural, petrological, and chronological constraints from eastern India and implications for the $\sim 1.0 \mathrm{Ga}$ assembly of greater India; J. Geol. 122 411-432, https://doi.org/10.1086/676459.

Rudnick R L and Gao S 2003 Composition of the continental crust; Treatise Geochem. 3 1-64, https://doi.org/10.1016/ B0-08-043751-6/03016-4.

Saha A K 1994 Crustal evolution of Singhbhum-North Orissa, eastern India, memoir 2\%; Geological Society of India, Bangalore.

Saha A K, Bose R, Ghosh S N and Roy A 1977 Petrology and emplacement of the Mayurbhanj granite Batholiths, eastern India; In: Evolution of the orogenic belts of India (part2), Geol. Min. Met. Soc. India Bull. 49 1-34.

Sarkar S N and Saha A K 1962 A revision of Precambrian stratigraphy and tectonics of Singhbhum and adjacent region; Quart. J. Geol. Mineral. Metall. Soc. India 34 97-136.

Sarkar S N and Saha A K 1963 On the occurrence of two intersecting Precambrian orogenic belts in Singhbhum and adjacent areas; Geol. Mag. 100 69-92.

Sengupta P and Ray A 2012 Newer dolerite dykes, Jharkhand, India: A case study of magma generation, differentiation and metasomatism in a subduction zone setting; Geochem. J. 46 477-491, https://doi.org/10.2343/geochemj.1.0174.

Sengupta S, Paul D K, de Laeter J R, McNaughton N J, Bandopadhyay P K and de Smeth J B 1991 Mid-Archaean evolution of the eastern Indian craton: Geochemical and isotopic evidence from the Bonai pluton; Precamb. Res. 49 23-37, https://doi.org/10.1016/0301-9268(91)90054-E.

Sengupta P, Ray A and Pramanik S 2014 Mineralogical and chemical characteristics of newer dolerite dyke around Keonjhar, Orissa: Implication for hydrothermal activity in subduction zone setting; J. Earth Syst. Sci. 123 887-904, https://doi.org/10.1007/s12040-014-0440-1.

Shankar R, Vijayagopal B and Kumar A 2014 Precise Pb-Pb baddeleyite ages of 1765 ma for a Singhbhum 'newer dolerite' dyke swarm; Curr. Sci. 106 1306-1310.

Singh M R, Manikyamba C, Ray J, Ganguly S, Saha A, Rambabu S and Sawant S S 2016 Major, trace and platinum group element (PGE) geochemistry of archean iron ore group and proterozoic malangtoli metavolcanic rocks of Singhbhum craton, eastern India: Inferences on mantle melting and sulphur saturation history; Ore Geol. Rev. 72 1263-1289, https://doi.org/10.1016/J.OREGEOREV. 2015.04 .024 .

Sun S-S and McDonough W F 1989 Chemical and isotopic systematics of oceanic basalts: Implications for mantle composition and processes; Geol. Soc. London, Spec. Publ. 42 313-345, https://doi.org/10.1144/GSL.SP.1989.042.01. 19.

Upadhyay D, Chattopadhyay S, Kooijman E, Mezger K and Berndt J 2014 Magmatic and metamorphic history of Paleoarchean tonalite-trondhjemite-granodiorite (TTG) suite from the Singhbhum craton, eastern India; Precamb. Res. 252 180-190, https://doi.org/10.1016/j.precamres. 2014.07.011.

Vohra C P, Dasgupta S, Paul P K, Bishui P K, Gupta S N and Guha S 1991 Rb-Sr chronology and petrochemistry of granitoids from the south-eastern part of the Singhbhum craton, Orissa; J. Geol. Soc. India 38 5-22. 